Board of Governors of the Federal Reserve System

International Finance Discussion Papers

Number 531

December 1995

\title{
A CENTURY OF TRADE ELASTICITIES FOR CANADA, JAPAN, AND THE UNITES STATES
}

\author{
Jaime Marquez
}

NOTE: International Finance Discussion Papers are preliminary materials circulated to stimulate discussion and critical comment. Reference in publications to International Finance Discussion Papers (other than an acknowledgment that the writer has had access to unpublished material) should be cleared with the author or authors. 


\begin{abstract}
Virtually all that is known about the behavior of imports rests on studies estimating income and price elasticities with postwar data. But anyone examining the evolution of trade over the last century cannot avoid asking whether the postwar period provides enough information to characterize that behavior. Indeed, the literature ignoring that past offers a large range of elasticity estimates suggesting that the role of income and prices in determining imports is not known with any precision. This paper offers the first analysis of that role using data since 1890 for Canada, Japan, and the United States. Estimating the elasticities of the most popular model in the literature with 1890-1992 data, I find that income and prices do not affect imports whereas the opposite conclusion arises with postwar data. The difference in results stems from changes in the composition of expenditures between domestic and foreign products. As an alternative, I consider several models consistent with both optimization and the time-series properties of the data. These models predict substantial secular changes in income and price elasticities and confirm the importance of optimization for characterizing the behavior of imports.
\end{abstract}




\title{
A Century of Trade Elasticities for Canada, Japan, and the United States
}

\author{
Jaime Marquez ${ }^{1}$
}

One day a Spherey physicist, with nothing to do except brood in the flatness of things, wondered whether triangles made bigger would still be Euclidean. ... He soon discovered that as triangles were made larger the sum of the angles increased. Turning to circles he discovered that the circumference of a large circle was appreciably less than $2 \pi \mathrm{r}$. Moreover there existed a maximum size of triangle, and of circle. Beyond a certain radius, increasing the radius resulted in a smaller circle. He published these remarkable results and was lynched by the Keep Sphereyland Flat Society (emphasis in original). B. K. Ridley Time, Space, and Things $(1994,49)$.

If the hallmark of econometrics is the provision of structural estimates, then fifty years of work estimating income and price elasticities for imports is far from victorious. The income elasticity for U.S. imports, for example, could be less than one or greater than four, a range large enough to question both the invariance of such elasticities and the reliability of the most popular formulation used for their estimation--the log-linear model. ${ }^{2}$ This range of estimates is troublesome for studying international interdependencies and puzzling because it stems from a given model.

I argue here that the chief failing of existing work is the treatment of imports' elasticities as invariant to changes in the composition of expenditures between domestic and foreign products. This composition has changed over the last century and the log-linear model cannot take it into account when characterizing the role of income and prices in determining imports. Obtaining such

1 The author is a senior economist in the Division of International Finance of the Federal Reserve Board and a visiting associate professor at the School of Advanced International Studies, Johns Hopkins University. I have benefited from comments by F. Gerard Adams, William Barnett, David Bowman, Angus Deaton, Barry Eichengreen, Jon Faust, Isaiah Frank, Clive Granger, William Helkie, Dale Henderson, David Hendry, Lawrence Klein, Ulrich Kohli, Philip Lane, Cathy Mann, William Melick, Charles Pearson, James Riedel, Alan Winters, and participants in seminars at the Federal Reserve Board, the U.S. International Trade Commission, the 7th World Congress of the Econometric Society in Tokyo August 1995, and Johns Hopkins University. Jason Kunreuther provided very helpful assistance in collecting and assembling the data for Japan and Canada. The calculations use the following software: Troll, Limdep 5.0, PCGIVE 8.10, and PCFIML 8.10. The views expressed in this paper are the author's and should not be interpreted as reflecting those of the Board of Governors of the Federal Reserve System or other members of its staff.

2 The log-linear model explains the logarithm of import volume in terms of the logarithm of a measure of economic activity and the logarithm of the relative prices of imports. For surveys of the elasticity estimates associated with this model see Stern et al. (1976), Thursby and Thursby (1984), Goldstein and Khan (1985); Kohli (1991) and Marquez (1992) also review this literature and point to references that do not rely on the log-linear model. 
a characterization involves orienting the econometric work towards models that allow elasticities to change in response to changes in spending patterns.

I begin the analysis in section 2 by explaining the dispersion of elasticities in terms of the modeling assumptions used for their estimation; I focus on the estimates for Canada, Japan, and the United States published in 39 studies during 1946-1994. I find that the choice of estimation period is the most systematic factor accounting for the dispersion of estimates. This result means that treating elasticities as constant parameters, even if statistically valid for a given study, is not valid when all studies are considered as a whole. This puzzle between parameter constancy at the study level and parameter instability at the literature level arises because individual studies use brief estimation samples that do not overlap across studies. Short and discontinuous samples lack enough information for detecting parameter instability arising from secular changes in the composition of expenditures. Incorporating secular changes involves using the largest span of data available and, to that end, section 3 develops a data set for imports and its determinants from 1890 to 1992 for Canada, Japan, and the United States. In section 4, I estimate the elasticities of the log-linear model with this sample and find, however, that Canadian imports are not price responsive and that U.S. imports are not affected by either relative prices or income.

That these findings create a tension with a literature claiming a role for income and prices in determining imports is clear. I eliminate this tension in section 5 through the use of two models that allow elasticities to change in response to changes in the composition of expenditures: the Rotterdam model developed by Barten (1964), Theil (1965), and Barnett (1979), and the Almost Ideal model developed by Deaton and Muellbauer (1980a). Other models are available (Kohli 1991), but the ones used here are the clearest in showing that elasticities depend on the composition of expenditures. Section 6 shows how the elasticity estimates implied by these 
models fluctuate in response to changes in spending patterns. These results do not question the usefulness of elasticities for addressing questions involving international interdependencies but rather the assumption that elasticities are invariant to changes in the composition of expenditures.

\section{The Constancy of Illusions}

Table 1 summarizes the literature's estimates of income and price elasticities for imports of Canada, Japan, and the United States based on fifty years of econometric work with the log-linear model. ${ }^{3}$ The mean of the estimates suggests that imports are price elastic (with Japanese imports being less so) and income elastic. These means are not representative, however, because they conceal a large dispersion of estimates: from -0.3 to -4.8 for the price elasticity of U.S. imports and from 0.7 to 4.1 for the income elasticity of U.S. imports; the dispersion of estimates for Canada and Japan is comparable to that of the United States.

One might argue that comparing estimates over fifty years overstates the dispersion of estimates because advances in statistical methodology might disqualify estimates obtained twenty years ago. Assuming that new techniques give better results, I focus on the last five years of econometric work and find a narrowing in the range of estimates: The income elasticity ranges from 0.7 to 2.6 for the United States, from 0.5 to 2.0 for Canada, and from 0.4 to 1.7 for Japan; the price elasticity ranges from -0.3 to -1.5 for the United States, from -0.2 to -2.4 for Canada, and from -0.4 to -0.9 for Japan. These ranges remain, however, sufficiently large to suggest that the role of income and prices in determining imports is not known with any precision.

\footnotetext{
${ }^{3}$ Appendix A lists papers reporting econometric estimates of trade elasticities for single-equation models of aggregate import demand for Canada, Japan, and the United States. By design, the appendix excludes studies examining the structure of trade on the basis of factor content or using non-parametric methods; papers reporting econometric estimates for relatively small components of imports are not included in this survey.
} 


\begin{tabular}{|c|c|c|c|c|c|}
\hline \multicolumn{6}{|c|}{$\begin{array}{l}\text { Table 1 } \\
\begin{array}{l}\text { Estimated Income and Price Elasticities for Canada, Japan, and the United } \\
\text { States: Summary Statistics from Selected Studies }\end{array}\end{array}$} \\
\hline Elasticities & Mean & Std. Dev. & Minimum & Maximum & Studies \\
\hline $\begin{array}{l}\text { Canada } \\
\text { Price } \\
\text { Income }\end{array}$ & $\begin{array}{r}-1.336 \\
1.352 \\
\end{array}$ & $\begin{array}{l}0.704 \\
0.480 \\
\end{array}$ & $\begin{array}{r}-2.750 \\
0.440 \\
\end{array}$ & $\begin{array}{r}-0.200 \\
2.010 \\
\end{array}$ & 19 \\
\hline $\begin{array}{l}\text { Japan } \\
\text { Price } \\
\text { Income }\end{array}$ & $\begin{array}{r}-0.879 \\
1.078 \\
\end{array}$ & $\begin{array}{l}0.775 \\
0.412 \\
\end{array}$ & $\begin{array}{r}-3.370 \\
0.350 \\
\end{array}$ & $\begin{array}{l}0.150 \\
1.690 \\
\end{array}$ & 15 \\
\hline $\begin{array}{l}\text { U.S. } \\
\text { Price } \\
\text { Income } \\
\end{array}$ & $\begin{array}{r}-1.312 \\
1.853 \\
\end{array}$ & $\begin{array}{l}0.916 \\
0.727 \\
\end{array}$ & $\begin{array}{r}-4.780 \\
0.730 \\
\end{array}$ & $\begin{array}{r}-0.290 \\
4.080 \\
\end{array}$ & 34 \\
\hline
\end{tabular}

To explain the dispersion of estimates, I use a fixed-effect model in which the ith study's elasticity (price or income) is the dependent variable and the study's modeling assumptions, other that the choice of model, are the explanatory variables:

$$
\epsilon_{i j}=\alpha_{0 j}+\alpha_{1 j} \text { Bretton-Woods }+\alpha_{2 j} \text { Static }+\alpha_{3 j} \text { Oil }+\alpha_{4 j} \text { Annual }+\alpha_{5 j} \text { Ptradeable }+u_{i j}
$$

where $\epsilon_{\mathrm{ij}}=$ Long-run elasticity estimate of the ith study for the jth country.

Bretton-Woods $=$ Dummy variable equal to one if the sample includes the Bretton Woods period.

Static $=$ Dummy variable equal to one if the estimates abstract from delayed adjustments.

Oil = Dummy variable equal to one if the data on imports include oil imports.

Annual $=$ Dummy variable equal to one if the frequency of observation of the data is annual.

Ptradeable $=$ Dummy variable equal to one if the domestic price excludes non-tradeable products. $u_{i j} \sim N\left(0, \sigma_{i j}^{2}\right)$.

The parameter $\alpha_{0 j}$ is the prototype elasticity for the jth country from studies that exclude data from the Bretton-Woods period; allow for lagged responses; exclude oil from the measure of imports; employ either semi-annual or quarterly data; and use a domestic price index that includes nontradeable products. The other parameters in (1) measure the extent to which alternative modeling 
assumptions change the prototype elasticity. For example, if $\alpha_{1 \mathrm{j}}$ is significantly different from zero, then including data for the Bretton-Woods period has a significant effect on the elasticity estimates. The list of explanatory variables could include other modeling assumptions such as whether the estimates recognize the endogeneity of prices. Allowing for this extension is, however, difficult because studies reporting ordinary least squares (OLS) results also note the robustness of the results to the use of simultaneous-equation estimation methods. Thus the choice of estimation technique is a response to pre-testing (see Geraci and Prewo 1982, Helkie and Hooper 1988).

I estimate the parameters of (1) with weighted least squares using the precision of the longrun elasticity estimates as weights. ${ }^{4}$ The results reveal that the modeling assumptions included in (1) explain at least 50 percent of the variation of the literature's estimates (table 2). In addition, the estimation period is the most systematic factor explaining the dispersion of estimates for U.S. and Japanese elasticities, as reflected in a significant coefficient for the Bretton-Woods dummy, $\alpha_{1}{ }^{5}$ Canadian estimates are robust to the estimation period, an expected result given the experience of Canada with flexible exchange rates during 1950-61. To examine the robustness of this conclusion to the relatively small number of observations for Canada and Japan, I pool the data and find that the estimate of $\alpha_{1}$ is significant. Thus the importance of sample periods in accounting

\footnotetext{
4 This choice of weights implies that $\sigma_{i j}{ }^{2}=\sigma^{2} / T_{i j}$ where $T_{i j}$ is the t-statistic of the ith elasticity estimate. Thus the weight that I use is $\sqrt{ } T_{i j}$. I use LIMDEP 5.0 for this estimation.

5 The negative $\alpha_{1}$ means that the estimated price elasticities for the post Bretton-Woods period are lower (in absolute terms) than the estimates for the Bretton-Woods period; estimated income elasticities show the opposite pattern. Table 2 also shows that U.S. and Canadian price elasticities are sensitive to the choice of domestic-price index. This result suggests that excluding domestic non-tradeable products from the price index makes imports and domestic products more comparable and raises (in absolute terms) the estimated price elasticity.
} 
Table 2

Estimation Results from Fixed-Effect Model of Trade Elasticities (t-statistics in parentheses)

$$
\epsilon_{\mathrm{ij}}=\alpha_{0 \mathrm{j}}+\alpha_{1 \mathrm{j}} \text { Bretton-Woods }+\alpha_{2 \mathrm{j}} \text { Static }+\alpha_{3 \mathrm{j}} \mathrm{Oil}+\alpha_{4 \mathrm{j}} \text { Annual }+\alpha_{5 \mathrm{j}} \text { Ptradeable }+\alpha_{6} \text { Canada }+\alpha_{7} \text { Japan }+\mathrm{u}_{\mathrm{ij}}
$$

\begin{tabular}{|c|c|c|c|c|c|c|c|c|}
\hline \multirow[t]{2}{*}{ Variable } & \multicolumn{2}{|c|}{ Canada (19 obs.) } & \multicolumn{2}{|c|}{ Japan (15 obs.) } & \multicolumn{2}{|c|}{ U.S. $(33 \text { obs. })^{\mathrm{a}}$} & \multicolumn{2}{|c|}{ Pooled (67 obs.) } \\
\hline & Income & Price & Income & Price & Income & Price & Income & Price \\
\hline Intercept & $\begin{array}{c}2.26 \\
(8.36)\end{array}$ & $\begin{array}{c}-2.26 \\
(-2.85)\end{array}$ & $\begin{array}{c}1.05 \\
(2.96)\end{array}$ & $\begin{array}{c}0.96 \\
(0.94)\end{array}$ & $\begin{array}{c}2.19 \\
(24.93)\end{array}$ & $\begin{array}{c}-1.28 \\
(-5.50)\end{array}$ & $\begin{array}{c}2.13 \\
(15.90)\end{array}$ & $\begin{array}{c}-1.01 \\
(-3.48)\end{array}$ \\
\hline $\begin{array}{l}\text { Bretton- } \\
\text { Woods }\end{array}$ & $\begin{array}{c}-0.05 \\
(-0.22)\end{array}$ & $\begin{array}{c}-0.19 \\
(-0.43)\end{array}$ & $\begin{array}{c}0.04 \\
(0.11)\end{array}$ & $\begin{array}{c}-1.97 \\
(-3.88)\end{array}$ & $\begin{array}{c}-0.66 \\
(-3.78)\end{array}$ & $\begin{array}{c}-0.45 \\
(-1.93)\end{array}$ & $\begin{array}{c}-0.28 \\
(-1.94)\end{array}$ & $\begin{array}{c}-0.53 \\
(-2.51)\end{array}$ \\
\hline Static & $\begin{array}{c}-0.62 \\
(-2.40)\end{array}$ & $\begin{array}{c}0.56 \\
(0.73)\end{array}$ & $\begin{array}{c}-0.23 \\
(-0.41)\end{array}$ & $\begin{array}{c}3.29 \\
(2.96)\end{array}$ & $\begin{array}{c}0.46 \\
(1.46)\end{array}$ & $\begin{array}{c}0.74 \\
(2.24)\end{array}$ & $\begin{array}{c}-0.01 \\
(-0.05)\end{array}$ & $\begin{array}{c}0.66 \\
(2.26)\end{array}$ \\
\hline Oil & $\begin{array}{c}-0.01 \\
(-0.02)\end{array}$ & $\begin{array}{c}0.20 \\
(0.47)\end{array}$ & $\begin{array}{c}0.51 \\
(1.63)\end{array}$ & $\begin{array}{l}-1.75 \\
(-4.14)\end{array}$ & $\begin{array}{c}0.22 \\
(2.00)\end{array}$ & $\begin{array}{c}0.54 \\
(2.81)\end{array}$ & $\begin{array}{c}0.16 \\
(1.28)\end{array}$ & $\begin{array}{c}0.09 \\
(0.47)\end{array}$ \\
\hline Annual & $\begin{array}{c}0.15 \\
(0.57)\end{array}$ & $\begin{array}{c}0.40 \\
(0.58)\end{array}$ & $\begin{array}{c}-0.02 \\
(-0.07)\end{array}$ & $\begin{array}{c}-0.99 \\
(-0.93)\end{array}$ & $\begin{array}{c}-0.64 \\
(-2.23)\end{array}$ & $\begin{array}{c}0.13 \\
(0.39)\end{array}$ & $\begin{array}{c}-0.17 \\
(-1.08)\end{array}$ & $\begin{array}{c}0.15 \\
(0.54)\end{array}$ \\
\hline Ptradeable & $\begin{array}{c}-0.49 \\
(-2.26)\end{array}$ & $\begin{array}{c}-0.14 \\
(-0.23)\end{array}$ & $\begin{array}{c}-0.24 \\
(-1.35)\end{array}$ & $\begin{array}{c}-0.34 \\
(-0.37)\end{array}$ & $\begin{array}{c}-0.01 \\
(-0.05)\end{array}$ & $\begin{array}{c}-0.73 \\
(-3.46)\end{array}$ & $\begin{array}{c}-0.24 \\
(-2.04)\end{array}$ & $\begin{array}{c}-0.50 \\
(-2.01)\end{array}$ \\
\hline Canada & -- & -- & -- & -- & -- & -- & $\begin{array}{c}-0.30 \\
(-2.20)\end{array}$ & $\begin{array}{c}-0.31 \\
(-1.46)\end{array}$ \\
\hline Japan & -- & -- & -- & -- & -- & -- & $\begin{array}{c}-0.73 \\
(-5.08) \\
\end{array}$ & $\begin{array}{c}0.23 \\
(0.94) \\
\end{array}$ \\
\hline $\mathrm{R}^{2}$ & 0.54 & 0.48 & 0.66 & 0.81 & 0.70 & 0.54 & 0.43 & 0.32 \\
\hline S.E.R. & 0.24 & 0.54 & 0.25 & 0.69 & 0.29 & 0.51 & 0.44 & 0.74 \\
\hline
\end{tabular}

Definitions:

$\epsilon_{i}=$ Estimate of the long-run elasticity of the ith study.

Bretton-Woods = Dummy variable equal to one if the sample includes the Bretton-Woods period.

Static $=$ Dummy variable equal to one if the estimation abstracts from delayed adjustments.

Oil = Dummy variable equal to one if imports include oil.

Annual $=$ Dummy variable equal to one if the sample's frequency of observation is annual.

Ptradeable $=$ Dummy variable equal to one if the domestic price index excludes non-tradeables.

Canada $=$ Dummy variable equal to one if the estimate corresponds to Canadian imports.

Japan = Dummy variable equal to one if the estimate corresponds to Japanese imports.

The estimates of Wilson and Takacs (1979) for the United States are excluded from the estimation sample because they are outliers.

Source: Appendix A. 
for the dispersion of estimates is not an artifact of a small number of studies. ${ }^{6}$

The importance of the estimation period means that the assumed constancy of elasticities, even if correct for a given study, is not correct when all studies are considered as a whole. This paradox stems from the use of samples covering brief periods with little overlap as confirmed by figure 1 which shows the estimation samples from the 39 studies arranged by publication date. Reliance on short and discontinuous samples cannot detect parameter instability arising from secular forces and, so far, no study covers the postwar period as a whole. Equation (1), however, combines all of these sub-samples and uncovers the instability concealed by sample selection.

One explanation for this instability is the secular change in the share of expenditures devoted to foreign products. That changes in the composition of expenditures affect elasticities has been known since Alfred Marshall and from demand models based on optimization. ${ }^{7}$ Krugman's exchange-rate delinking hypothesis (Krugman 1989b) is, however, an alternative possibility. He argues that the volatility of exchange rates in the post Bretton-Woods period reduced the informational content of changes in exchange rates and lowered the price responsiveness of international trade. Because this increase in volatility of exchange rates is concomitant with changes in the composition of expenditures, I discriminate between these two hypotheses below. For now, the important point is that arbitrariness in the selection of the sample period is creating a dispersion in the estimates from the log-linear model and that addressing such

\footnotetext{
${ }^{6}$ This sensitivity analysis assumes that $\alpha_{i j}=\alpha_{i}$ for $i>0, \sigma_{i j}{ }^{2}=\sigma_{i}{ }^{2}$, and that differences in the estimates across countries can be captured through the inclusion of country dummies for Canada and Japan. The estimated prototype income elasticities are 2.1 for the United States, $1.8(=2.1-0.3)$ for Canada, and 1.4 for Japan; differences among these elasticities are statistically significant. The estimated prototype price elasticities are -1.0 for the United States, $-1.3(=-1.0-0.3)$ for Canada, and -0.8 for Japan; differences among these elasticities are not significant.

${ }^{7}$ In his chapter on the Elasticity of Wants, Marshall states that "The elasticity of demand is great for high prices, and great, or at least considerable, for medium prices; but it declines as the price falls; and gradually fades away if the fall goes so far that satiety level is reached." Marshall $(1961$, p.103).
} 


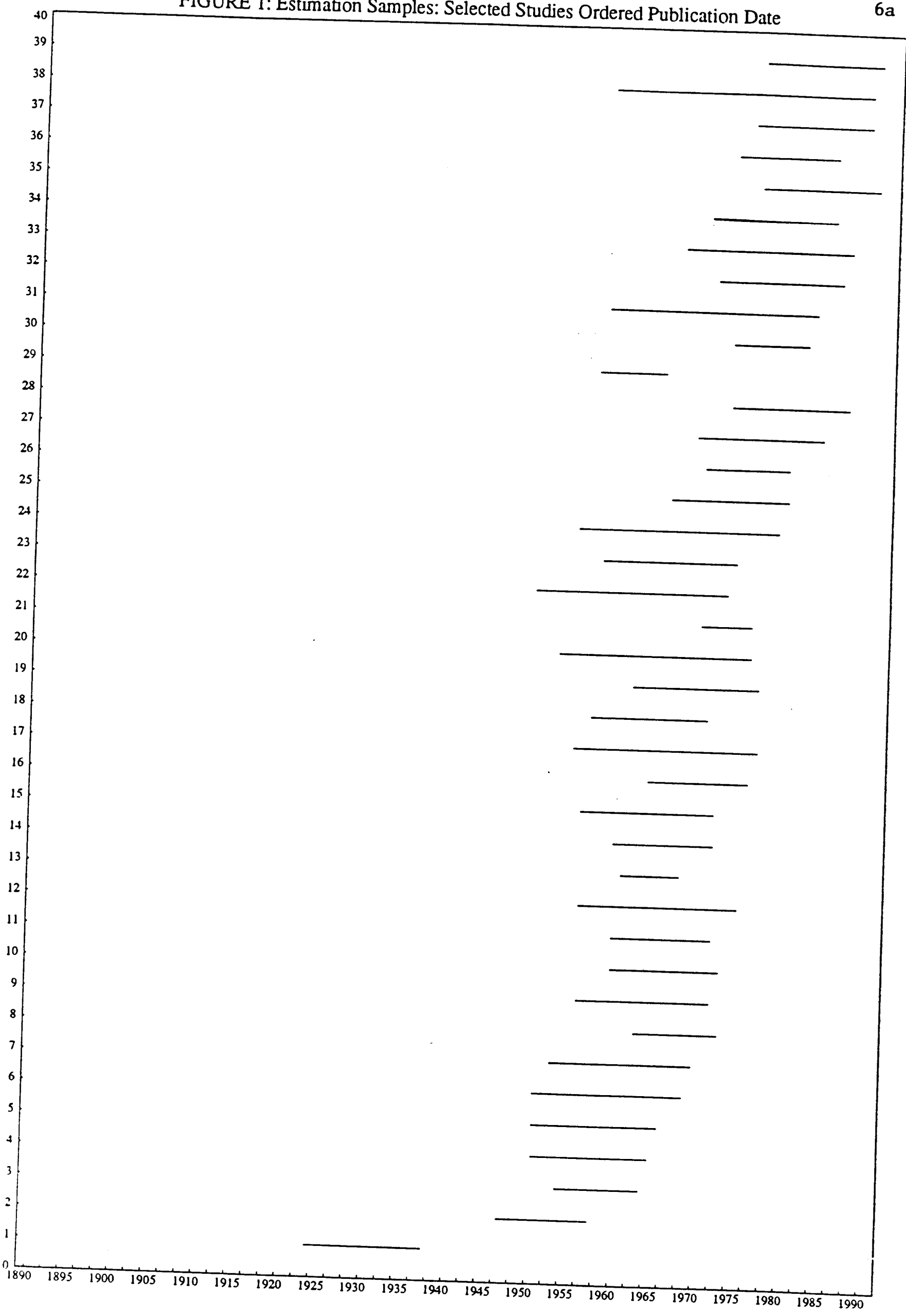


arbitrariness involves using the longest span of data available. I now turn to the description of a data set depicting the evolution of imports and its main determinants since $1890 .^{8}$

\section{Data}

Assembling series covering a century involves combining data sources using different assumptions such as the choice of base year for calculating constant-price magnitudes. To this end, I use the base year of the most recent data available, assume that growth rates are invariant to the choice of base year, and extrapolate backwards using the growth rates from older data sources. Assuming that growth rates are invariant to the choice of base year carries inaccuracies that should be taken into account when evaluating the results; ${ }^{9}$ appendix B lists the data sources.

Figure 2 displays the evolution of the relative price of imports, real per-capita expenditures, real per-capita imports, and the nominal share of imports in expenditures for Canada, Japan, and the United States since $1890 ;{ }^{10}$ table 3 reports the mean and standard deviations for the associated

8 One could argue that aggregation errors represent a third factor accounting for the instability in elasticity estimates. Specifically, if elasticity estimates for imports disaggregated across either countries or commodities are constant but they are aggregated with weights that are changing, then the resulting aggregate might exhibit instability because of the instability of the weights. Though mechanically correct, this proposition assumes that the disaggregated elasticities are invariant to changes in the composition (geographical or commodity) of imports. This invariance contradicts optimization unless the estimated income elasticities are one and the price elasticities are minus one (see Deaton and Muellbauer 1980b). Stern et al. (1976) and Alterman (1993) show that the disaggregated elasticities for imports differ from one and thus are not consistent with the implications of optimization. Thus I will not pursue further aggregation errors in this paper.

9 As a sensitivity analysis, however, I checked the correlation between the U.S. series based in 1987 prices with those of Romer (1989) who reports estimates of U.S. real GNP (and its deflator) for the period 1869-1929 in 1982 prices. The correlation between the series that I use and those reported by Romer, for 1890-1929, are 0.994 for real GNP and 0.998 for the GNP deflator.

${ }^{10}$ Figure 2 includes the results from the augmented Dickey-Fuller (ADF) test which cannot reject the hypothesis that the variables are integrated of order one. Given the abrupt changes recorded for several of the series, I also include the ADF statistic for two subperiods: 1890-1937 and 1952-1992. The results do not reject the hypothesis that these variables are integrated of order one for each subperiod. Also, I consider the case of multiple unit roots using the method of Dickey and Pantula (1987) and found no evidence of multiplicity of unit roots. 

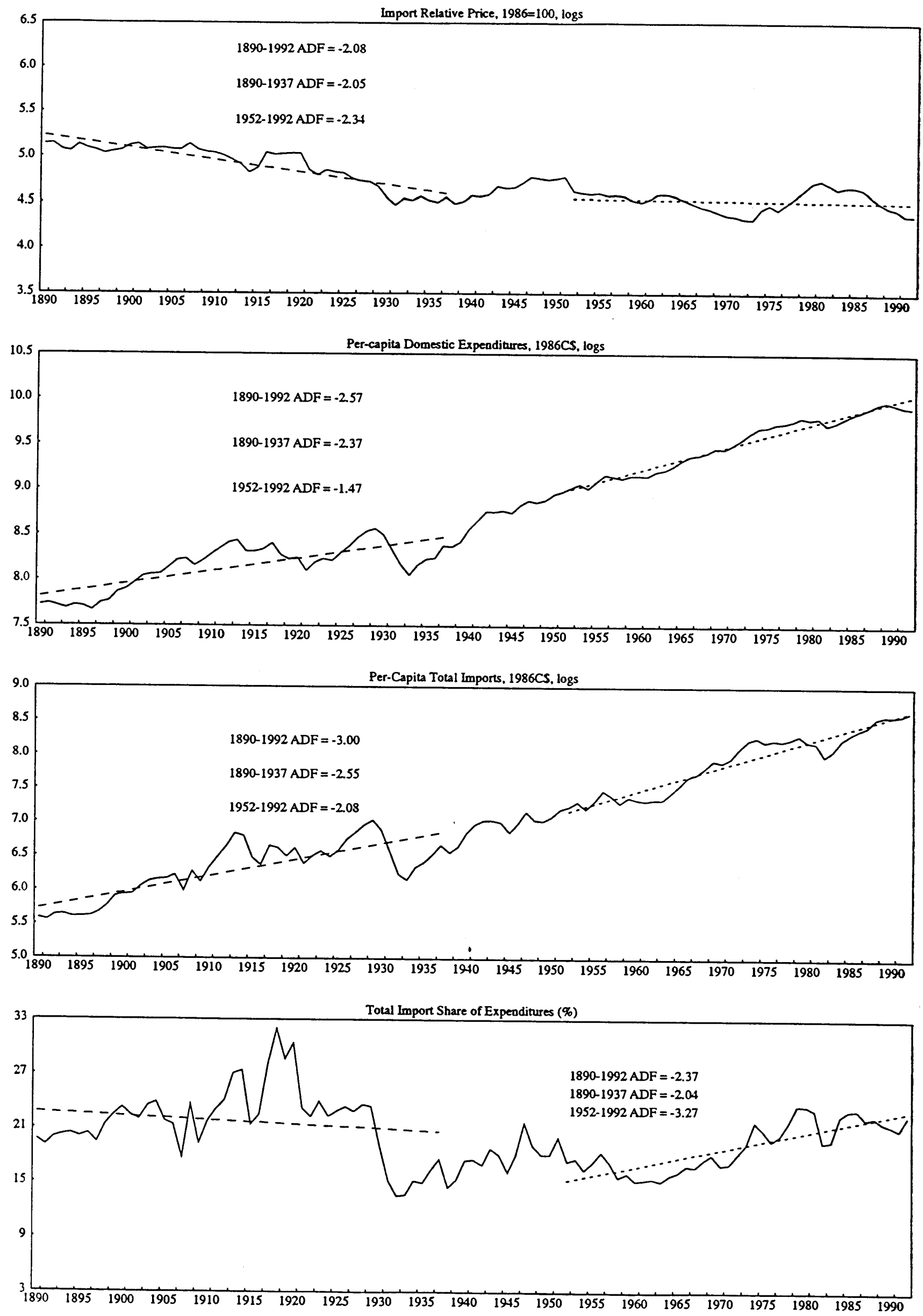
FIGURE 2: Japanese Expenditures, Prices, and Income: 1890-1992

Import Relative Price, 1985=100, logs

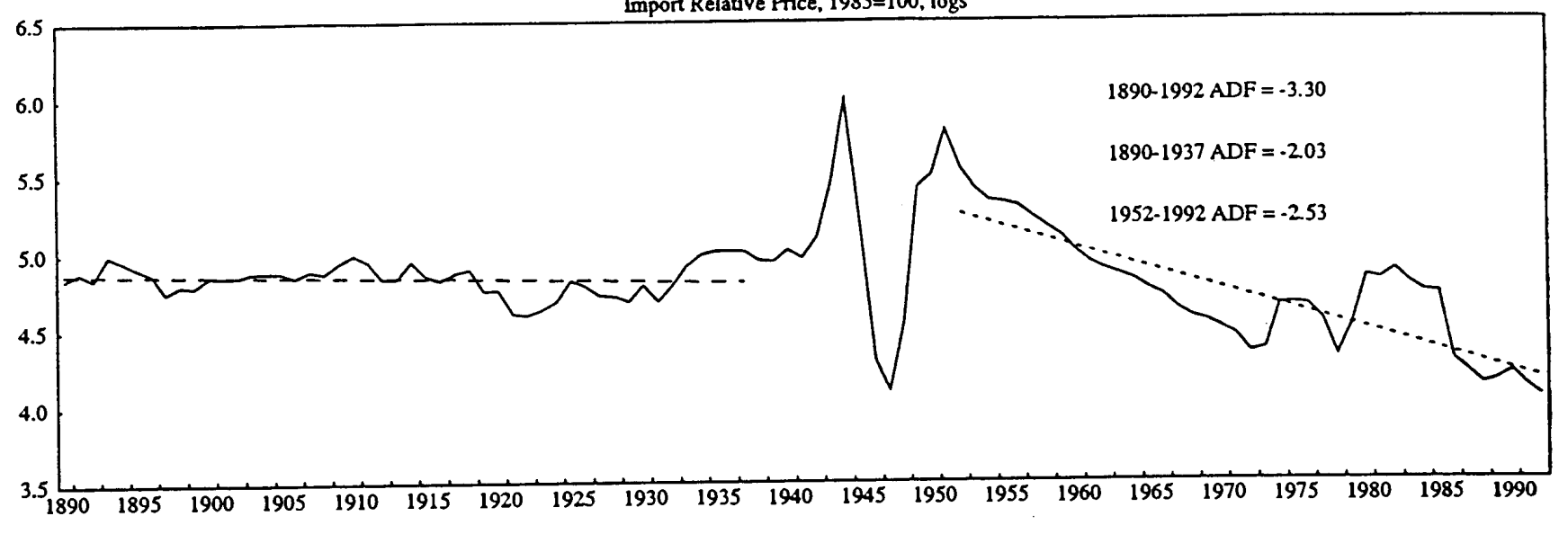

Per-capita Domestic Expenditures, 1985 yen (mill.), logs

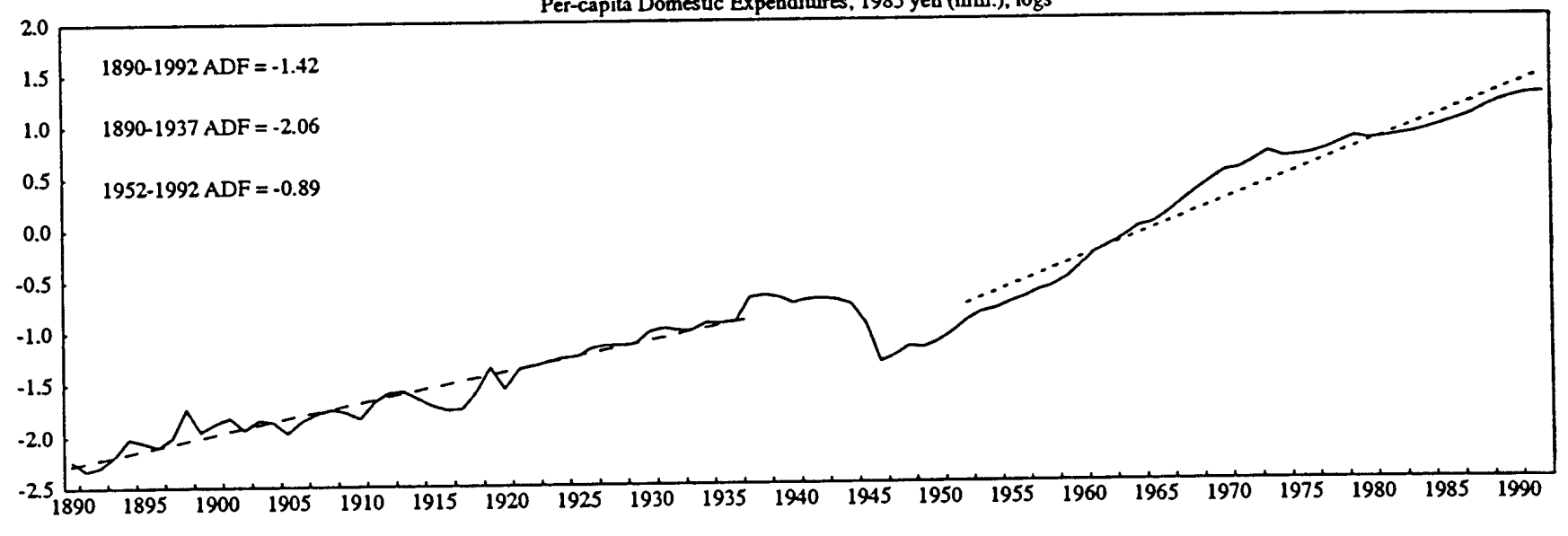

Per-capita Total Imports, 1985 yen (mill) logs,

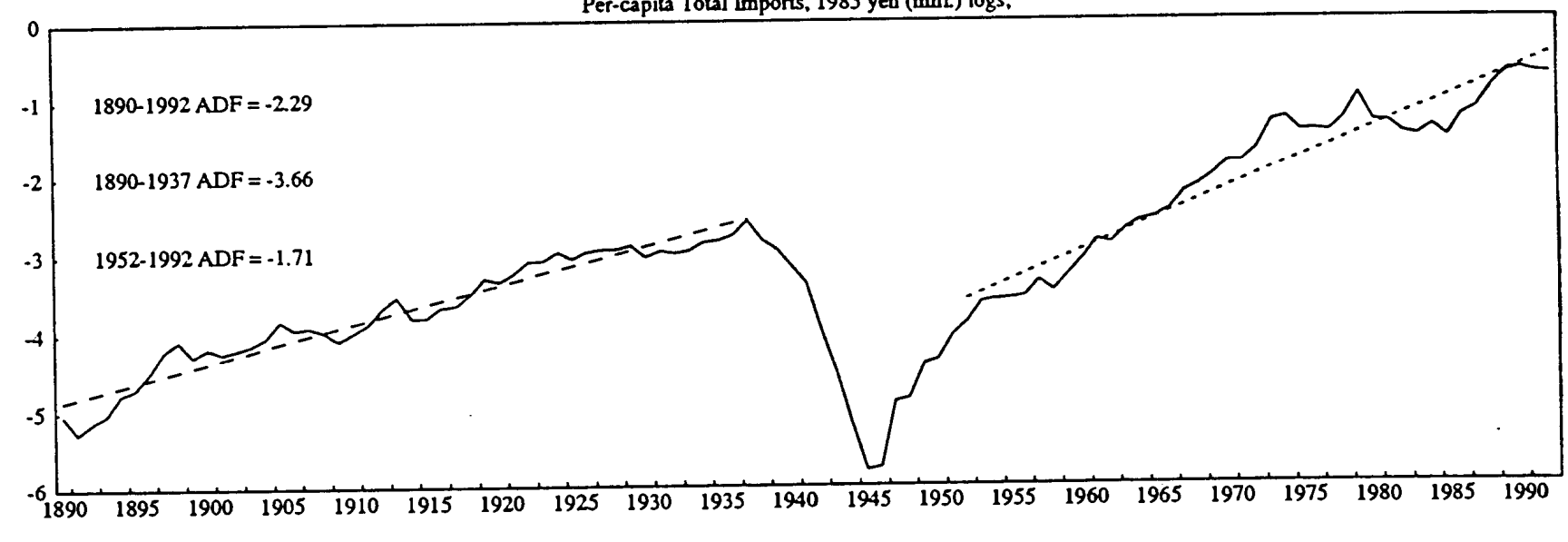

Total Import Sbare of Expenditures (\%)

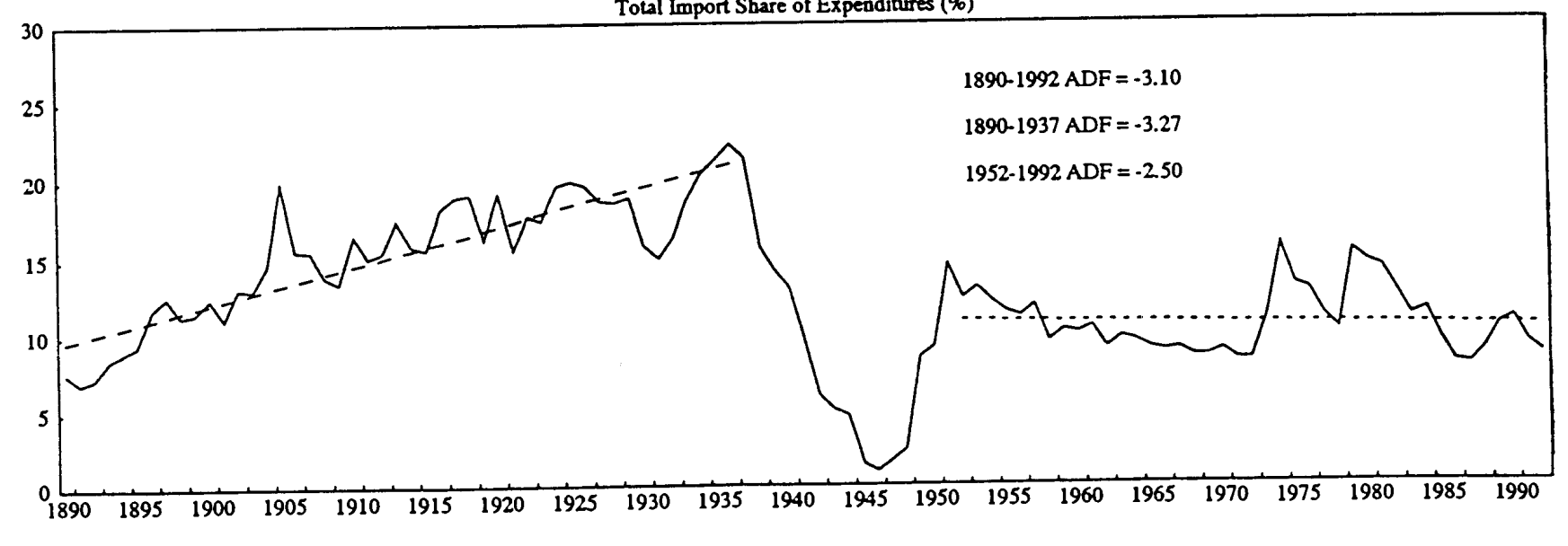


FIGURE 2: U.S. Expenditures, Prices, and Imports: 1890-1992
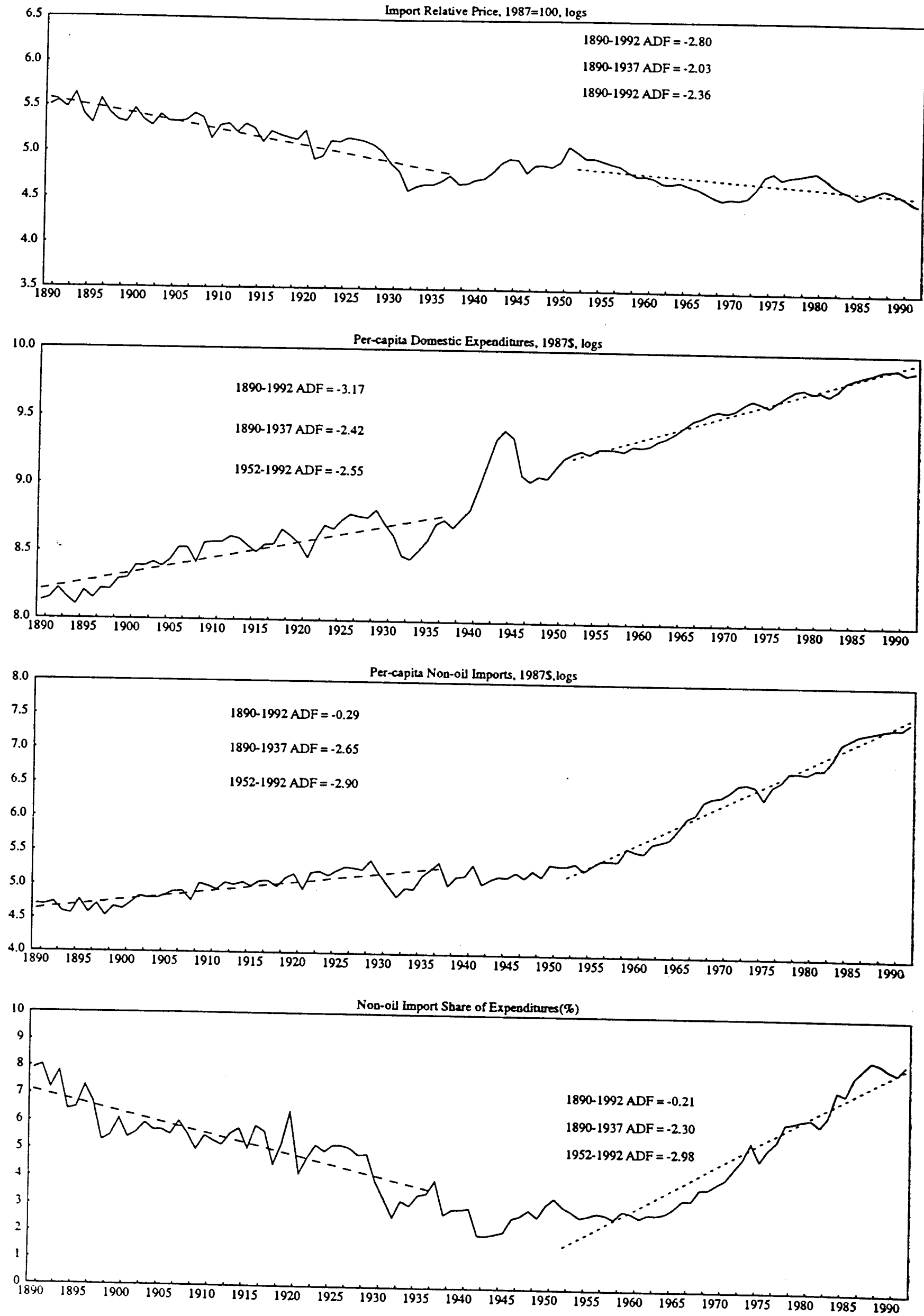
growth rates over three periods: 1890-1937, 1952-1992, and 1890-1992."

\begin{tabular}{|c|c|c|c|c|c|c|}
\hline \multicolumn{7}{|c|}{$\begin{array}{c}\text { Table } 3 \\
\text { Relative Price of Imports, Real Spending, and Real Imports--Growth Rates } \\
\text { Canada, Japan, and the United States: } 1890-1992 \\
\text { Mean and Standard Deviation (Percent) }\end{array}$} \\
\hline & \multicolumn{2}{|c|}{$1890-1937$} & \multicolumn{2}{|c|}{$1952-1992$} & \multicolumn{2}{|c|}{$1890-1992$} \\
\hline & Mean & Std. Dev. & Mean & Std. Dev. & Mean & Std. Dev. \\
\hline $\begin{array}{l}\text { Canada } \\
\text { Price } \\
\text { Spending } \\
\text { Imports } \\
\end{array}$ & $\begin{array}{r}-1.20 \\
1.39 \\
2.29 \\
\end{array}$ & $\begin{array}{r}5.63 \\
7.45 \\
14.46 \\
\end{array}$ & $\begin{array}{r}-0.59 \\
2.20 \\
3.52 \\
\end{array}$ & $\begin{array}{l}4.91 \\
3.51 \\
8.19 \\
\end{array}$ & $\begin{array}{l}-0.74 \\
2.15 \\
3.02 \\
\end{array}$ & $\begin{array}{l}5.20 \\
5.87 \\
11.79 \\
\end{array}$ \\
\hline $\begin{array}{l}\text { Japan } \\
\text { Price } \\
\text { Spending } \\
\text { Imports }\end{array}$ & $\begin{array}{l}0.34 \\
3.28 \\
5.27 \\
\end{array}$ & $\begin{array}{r}7.29 \\
10.82 \\
12.65 \\
\end{array}$ & $\begin{array}{r}-3.61 \\
5.51 \\
8.43 \\
\end{array}$ & $\begin{array}{r}12.36 \\
4.18 \\
15.88 \\
\end{array}$ & $\begin{array}{c}-0.79 \\
3.47 \\
4.44 \\
\end{array}$ & $\begin{array}{c}21.73 \\
9.05 \\
22.37 \\
\end{array}$ \\
\hline $\begin{array}{l}\text { U.S. } \\
\text { Price } \\
\text { Spending } \\
\text { Imports }\end{array}$ & $\begin{array}{r}-1.57 \\
1.34 \\
1.43 \\
\end{array}$ & $\begin{array}{r}11.62 \\
7.08 \\
11.85 \\
\end{array}$ & $\begin{array}{r}-1.25 \\
1.57 \\
5.41 \\
\end{array}$ & $\begin{array}{l}4.72 \\
2.49 \\
8.48 \\
\end{array}$ & $\begin{array}{c}-0.96 \\
1.72 \\
2.76 \\
\end{array}$ & $\begin{array}{c}8.93 \\
6.64 \\
11.35 \\
\end{array}$ \\
\hline
\end{tabular}

The relative price of imports, measured as the ratio between the tariff-adjusted deflator for imports and the GNP deflator, declines faster in the prewar period (1890-1937) than in the postwar period (1952-92), except for Japan (table 3); figure B1 of appendix B shows the evolution of the various components determining the relative price of imports. ${ }^{12}$ The overall rates of decline

$"$ Table 3 reports the geometric mean of growth rates; arithmetic means suffer from outliers and distort estimates of long-term trends. Branson (1980), Dornbusch and Fischer (1986), and Lipsey (1994) document the evolution of U.S. openness but do not quantify the role of income and prices in explaining U.S. imports. Ohkawa (1957), Cohen (1958), Baba and Tatemoto (1969), Ohkawa and Rosovsky (1973), Ohkawa and Shinohara (1979), Minami (1994) document the evolution of Japanese openness; Baba and Tatemoto (1969) and Minami (1994) estimate income and price elasticities from the log-linear model for the pre-war and postwar periods. For Canada, see Caves and Holton (1959), Officer (1968), Marr and Patterson (1980); Officer (1968) estimates income and price effects of Canadian trade using postwar data.

${ }^{12}$ For Japan, the relatively large rate of decline in the relative price of imports is due to a 400 percent depreciation of the yen in 1948 (Liesner, 1989, p. 55) which raises the relative price of imports and overstates the degree of price decline in the postwar period. In figure 2, Japan shows two additional large changes in the relative price of imports. The first upswing (1941-42) is due to the increase in the price of imports arising from the increased costs of product delivery and the general scarcity of commodities induced by WWII. The subsequent decline stems from an inflationary episode in which domestic prices grew in excess of 200 percent per year during 1943-46 (Cohen, 1949, p. 459, table 75; Minami, 1994, p. 45); this inflationary period ended with the Dodge plan in 1949 (Minami 1994, p. 45). 
are 0.7 percent for Canada, 0.8 percent for Japan, and 1.0 percent for the United States. The downward trend for the relative price is not smooth with its postwar volatility declining for the United States and increasing for Japan. ${ }^{13}$

Growth in per-capita expenditures, measured as real GNP plus real imports of goods and services minus real exports of goods and services, is slower and more volatile during the prewar period than in the postwar period for all three countries. The overall growth rates are 2.2 percent for Canada, 3.5 percent for Japan, and 1.7 percent for the United States. As figure 2 shows, spending's upward trend breaks during the Great Depression and the war disruption of 1942-46.

Per-capita imports grow faster in the postwar period than in the prewar period in all three countries with the United States showing the largest increase. The overall growth rates are 3.0 percent for Canada, 4.4 percent for Japan, and 2.8 percent for the United States. Imports' upward trend breaks in two instances: The contraction in Japanese imports during the 1940s and the contraction in U.S. and Canadian imports during the tariff wars of the 1930s. Volatility in the growth rate of imports during the postwar period declines for Canada and the United States; for Japan, import's growth shows a small increase in volatility.

Inspecting the composition of expenditures indicates that the share of imports is generally greater in the beginning of this century than in the subsequent period, a pattern explained by Kuznets (1966, chapter 6). Specifically, the share of imports in Canadian expenditures, though rising in the postwar period, is below the share of imports in the prewar period. For Japan, this share rises during the prewar period and falls in the subsequent period. For the United States, the import share declines from eight percent in 1890 to barely above two percent in 1942; since then,

\footnotetext{
13 Pricing and distribution of Japanese imports during the prewar period was under the control of domestic cartels which kept relative prices largely unchanged (Minami 1994, p.184); the influence of these cartels diminished in the postwar period.
} 
this share rises steadily reaching in 1992 the same value it had in 1890 . These fluctuations in import shares question the usefulness of the log-linear model for estimating elasticities because this model requires constant expenditure shares in order to be consistent with optimization (see Deaton and Muellbauer 1980b, Kohli 1991).

To illustrate this point, figure 3 plots the logarithm of the import-expenditure ratio against the logarithm of the relative price of imports for three periods: $1890-1937,1952-1992$, and 18901992; each plot shows the regression line associated with $\ln \left(\mathrm{m}_{\mathrm{t}} / \mathrm{y}_{\mathrm{t}}\right)=\zeta_{0}+\zeta_{1} \ln \left(\mathrm{p}_{\mathrm{mt}} / \mathrm{p}_{\mathrm{d} t}\right)$ where $\mathrm{m}_{\mathrm{t}}$ is per-capita real imports; $y_{t}$ is per-capita real expenditures; $p_{m t}$ is the tariff-adjusted price of imports; and $\mathrm{p}_{\mathrm{dt}}$ is the GNP deflator. The slope of the regression line for Canadian data varies from -0.54 to -0.75 whereas the slope for U.S. data varies from -0.08 to -2.39 . This dispersion of estimates underscores the sensitivity of the log-linear formulation to secular changes in spending patterns. These results, however, do not control for unusual events, such as wars; assume a unitary income elasticity and a constant price elasticity; and abstract from other modeling considerations, such as dynamic adjustments. I now turn to these modeling issues.

\section{The Log-linear Model}

To quantify the effects of ignoring secular changes in the composition of expenditures, I estimate the parameters of the log-linear model:

$$
\ln \left(m_{1}\right)=\beta_{0}+\beta_{1}(L) \ln \left(m_{t-1}\right)+\beta_{2}(L) \ln \left(y_{t}\right)+\beta_{3}(L) \ln \left(p_{m t} / p_{d}\right)
$$

where $\beta_{i}(L)$ is a polynomial in the lag operator $L(i>0)$; I include dummy variables in (2) to control for war-related disruptions. ${ }^{14}$ The long-run elasticities are $\beta_{2}(1) /\left[1-\beta_{1}(1)\right]$ for income and

\footnotetext{
${ }^{14}$ As figure 2 indicates, the $\mathrm{ADF}$ test results cannot reject the hypothesis that the variables in (2) are integrated of order one which means that equation (2) is balanced. Note that (2) is an unrestricted Autoregressive Distributed Lag and its long-run parameters are identical to those given by the Error-Correction formulation (see Banerjee et al., 1993,
} 

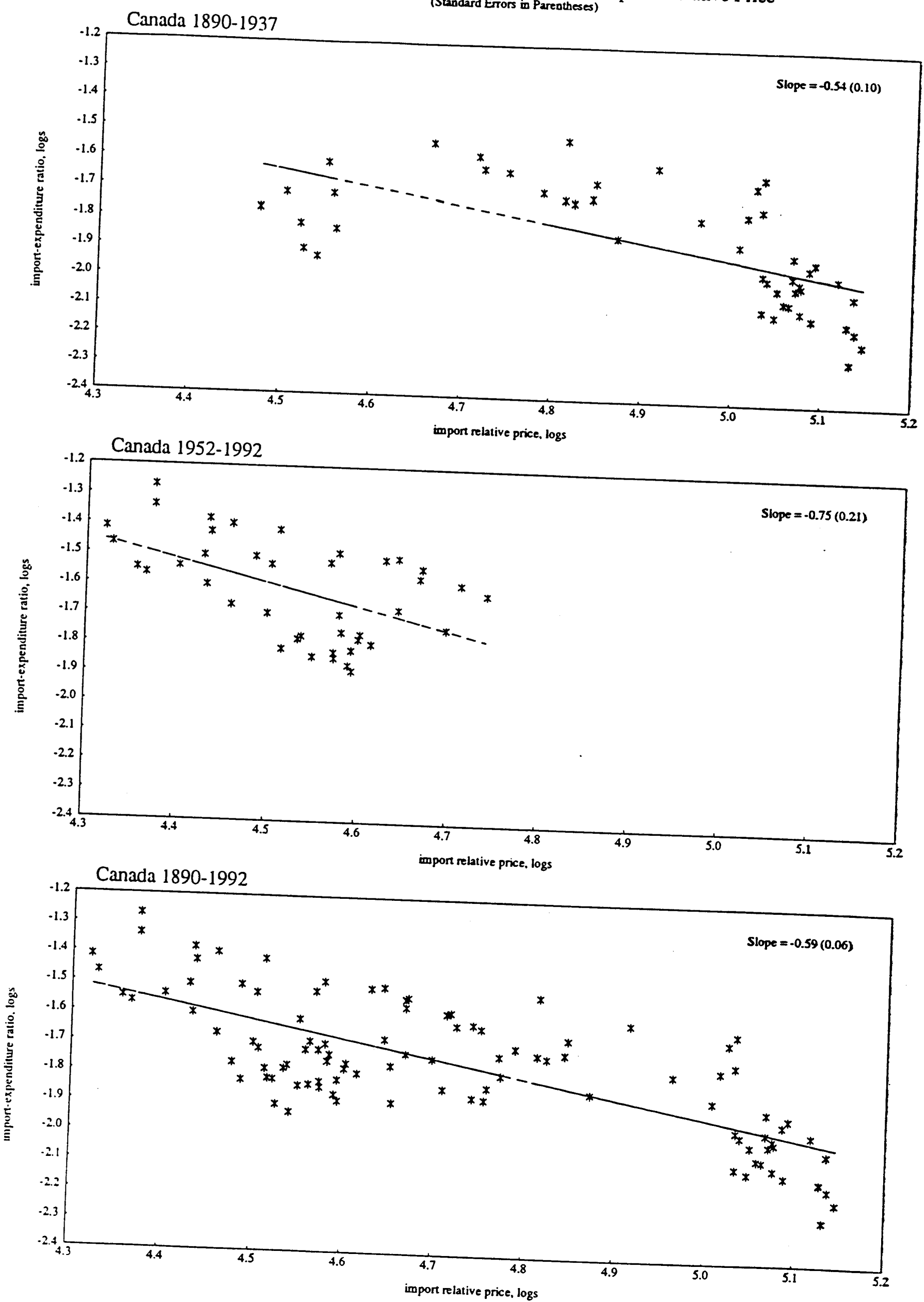
FIGURE 3: Import-Expenditure Ratio and Imports Relative Price
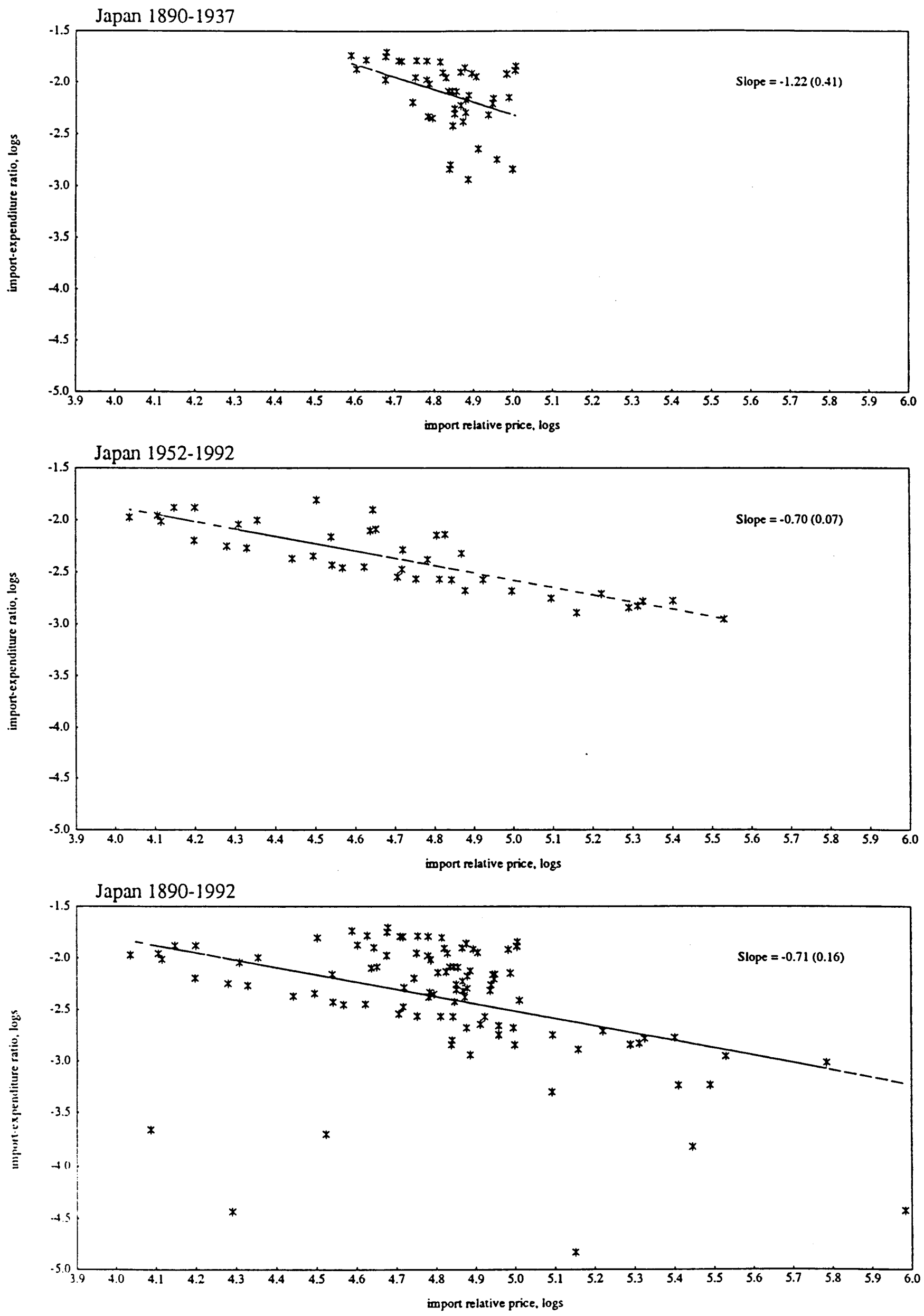

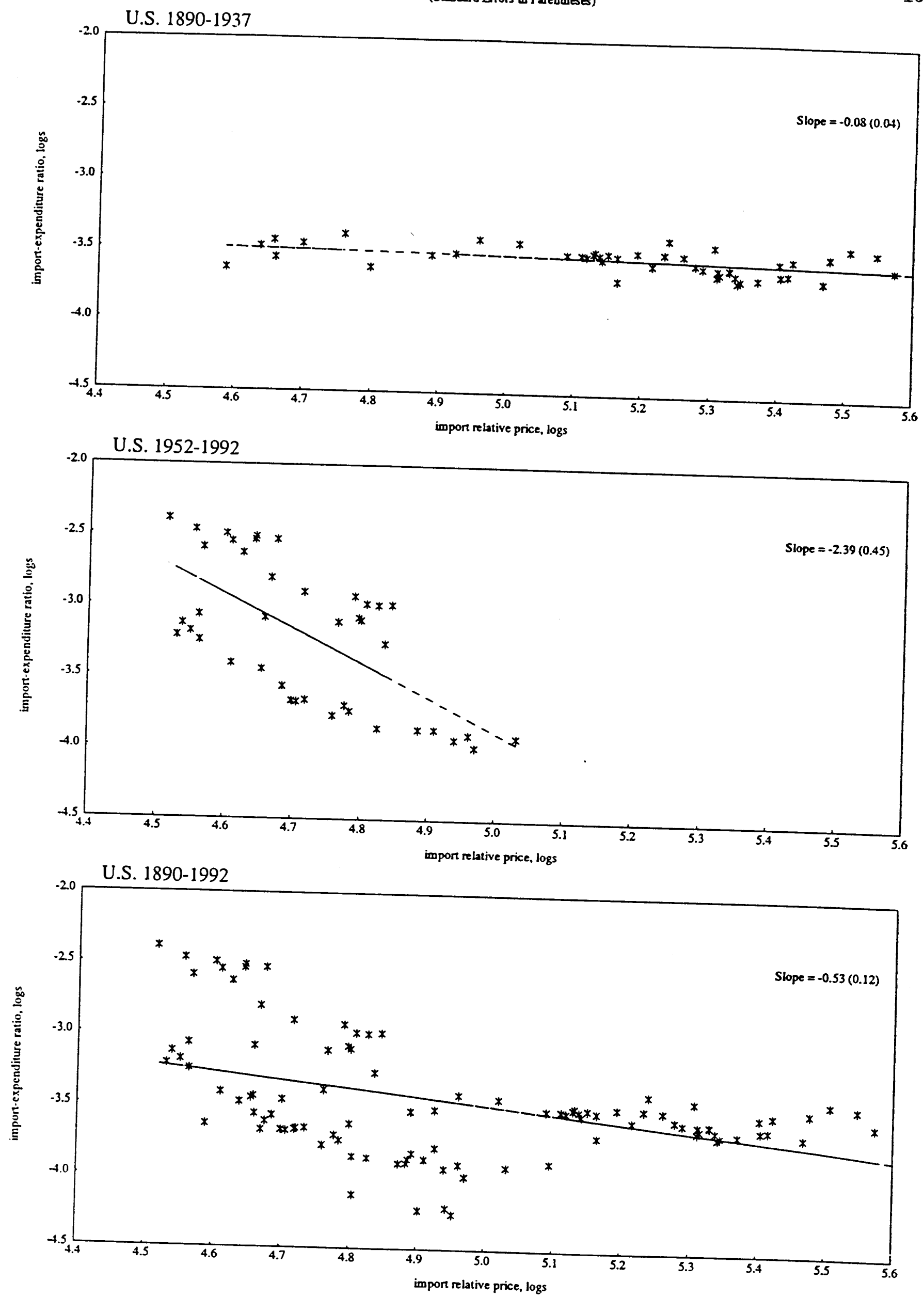
$\beta_{3}(1) /\left[1-\beta_{1}(1)\right]$ for the relative price of imports; if $\beta_{1}(1)=1$ then imports lack a steady state.

Table 4 reports the long-run elasticity estimates for two samples--1890-1992 and 1951-1992--and

the test results for several hypotheses: long-run price homogeneity, joint significance of income and price elasticities; serial independence and homoskedasticity in the residuals; and functional form. ${ }^{15}$

For Canada, the elasticities based on postwar data alone are -0.7 for prices and 1.6 for income with both estimates being significant; including prewar data for estimation yields, however, a price elasticity that is negligible and statistically insignificant, even though the results support the maintained assumptions for the residual and functional form. For Japan, the price elasticity based on postwar data is -0.7 and the income elasticity is 1.1 ; both estimates are statistically significant. Including the prewar data for estimation yields a price elasticity of -1.8 and an income elasticity of 0.7 with both estimates being statistically significant. Thus including prewar data suggests that imports are price elastic and income inelastic whereas the opposite characterization emerges when the estimates rely solely on postwar data; Baba and Tatemoto (1968) already report parameter instability for Japanese imports. For the United States, the price elasticity based on postwar data is -0.54 and the income elasticity is 3.25 , with both estimates being significant. The inclusion of prewar data leads, however, to a spectacular deterioration of the point estimates with the Wald test

section 2.5). I determine the number of lags by a process of lag-elimination that begins with four lags and sequentially reduces insignificant lags. I retain, however, the same number of lags for each variable.

${ }^{15}$ I use a t-statistic to test the null hypothesis that the (absolute value of the) coefficient for the price of imports equals the coefficient for the domestic price; for the hypothesis that long-run coefficients are jointly equal to zero, I use a Wald test. For serial independence, I apply an F-test to the null hypothesis that the coefficients of an AR(2) for the residual are zero. For homoskedasticity, I use Engle's ARCH test (Engle, 1982). For the choice of functional form, I use Ramsey's RESET test statistic. These tests are implemented in Doornik and Hendry (1994). 
Table 4

Income and Price Elasticities from Log-linear Model for Canada, Japan, and United States: 1890-1992

$$
\ln \left(m_{\mathrm{t}}\right)=\beta_{0}+\beta_{1}(\mathrm{~L}) \ln \left(\mathrm{m}_{\mathrm{t}-1}\right)+\beta_{2}(\mathrm{~L}) \ln \left(\mathrm{y}_{\mathrm{t}}\right)+\beta_{3}(\mathrm{~L}) \ln \left(\mathrm{p}_{\mathrm{mt}} / \mathrm{p}_{\mathrm{d} t}\right)
$$

\begin{tabular}{l|c|c|c|c|c|c|c|c|c} 
Canada & \multicolumn{2}{|c|}{ Elasticities } & \multicolumn{9}{c|}{ Test Statistics } \\
\hline Sample & Income & Price & $\begin{array}{c}\text { Price }^{1} \\
\text { Homogeneity }\end{array}$ & Wald $^{2}$ & $\begin{array}{c}\text { No Serial } \\
\text { Correlation }\end{array}$ & $\begin{array}{c}\text { Constant } \\
\text { Variance }\end{array}$ & RESET $^{\text {s }}$ & SER(\%) & $R^{2}$ \\
\hline $1890-1992$ & $1.30^{*}$ & -0.09 & 0.69 & $0.00^{* *}$ & 0.73 & 0.40 & 0.38 & 7.12 & 0.99 \\
$1952-1992$ & $1.58^{*}$ & $-0.72^{*}$ & 0.68 & $0.00^{* *}$ & 0.76 & 0.38 & 0.69 & 2.57 & 0.99 \\
\hline \hline
\end{tabular}

\begin{tabular}{l|c|c|c|c|c|c|c|c|c} 
Japan & \multicolumn{2}{|c|}{ Elasticities } & \multicolumn{6}{c|}{ Test Statistics } \\
\hline Sample & Income & Price & $\begin{array}{c}\text { Price } \\
\text { Homogeneity }\end{array}$ & Wald & $\begin{array}{c}\text { No Serial } \\
\text { Correlation }\end{array}$ & $\begin{array}{c}\text { Constant } \\
\text { Variance }\end{array}$ & RESET & SER(\%) & $R^{2}$ \\
\hline $1890-1992$ & $0.71^{*}$ & $-1.75^{*}$ & 0.12 & $0.00^{* *}$ & $0.04^{*}$ & 0.08 & 0.05 & 13.25 & 0.99 \\
$1952-1992$ & $1.09^{*}$ & $-0.66^{*}$ & 1.58 & $0.00^{* *}$ & 0.46 & 0.62 & 0.19 & 10.47 & 0.99 \\
\hline \hline
\end{tabular}

\begin{tabular}{l|c|c|c|c|c|c|c|c|c} 
U.S. & \multicolumn{2}{|c|}{ Elasticities } & \multicolumn{9}{c}{ Test Statistics } \\
\hline Sample & Income & Price & $\begin{array}{c}\text { Price } \\
\text { Homogeneity }\end{array}$ & Wald & $\begin{array}{c}\text { No Serial } \\
\text { Correlation }\end{array}$ & $\begin{array}{c}\text { Constant } \\
\text { Variance }\end{array}$ & RESET $^{\text {s }}$ & SER(\%) & $R^{2}$ \\
\hline $1890-1992$ & -63.42 & -40.49 & 1.09 & 1.00 & 0.45 & 0.54 & 0.57 & 7.57 & 0.99 \\
$1952-1992$ & $3.25^{*}$ & $-0.54^{*}$ & 1.06 & $0.00^{* *}$ & 0.28 & 0.92 & 0.78 & 3.59 & 0.99 \\
\hline \hline
\end{tabular}

Notes: $m$ is per-capita, real imports; $y$ is per-capita, real domestic expenditures; $p_{m}$ is the tariff-adjusted import price; $p_{d}$ is the GNP deflator; the income elasticity is $\beta_{2}(1) /\left[1-\beta_{1}(1)\right]$ and the price elasticity is $\beta_{3}(1) /\left[1-\beta_{1}(1)\right]$. The regression includes dummy variables: 1918, 1942, and 1946 for the United States; 1908, 1915 for Canada; 1938, 1942, 1945 for Japan. A* denotes rejection of the null hypothesis at the five percent significance level; ${ }^{* *}$ denotes rejection at the 1 percent significance level.

${ }^{1} \mathrm{~T}$-statistic for the hypothesis that the coefficient for the price of imports, in absolute value, equals the coefficient for the domestic price.

${ }^{2}$ Significance level for rejecting the hypothesis that the long-run coefficients are jointly equal to zero using Wald's test.

${ }^{3}$ Significance level for rejecting the hypothesis that the coefficients of an $A R(2)$ for the residual are zero using an F-test.

${ }^{4}$ Significance level for rejecting the hypothesis that residuals are homoskedastic using Engle's ARCH test.

${ }^{5}$ Significance level for rejecting the choice of functional form using Ramsey's RESET test statistic. 
rejecting the hypothesis that income and relative prices influence imports. ${ }^{16}$

These findings highlight a tension in empirical work: If elasticities are constant then Canadian imports are not price responsive and U.S. imports are not affected by either prices or income. If income and relative prices determine these imports, then their effects cannot be measured reliably with constant elasticities. Indeed, I apply Johansen's cointegration procedure (Johansen, 1988) and cannot identify a single cointegrating relation among the logarithms of imports, relative prices, and expenditures (table 5). This failure to find cointegration does not imply, however, a rejection of the imperfect-substitute model embodied in (2). Specifically, the solution to the first-order conditions of an optimization problem relates changes in purchases to changes in both expenditures and relative prices suggesting that changes in these variables should be cointegrated. The cointegration results of table 5 for differenced data support this prediction and suggest that modeling imports of these countries should use data in first differences. The next question is how to do this.

\section{Modeling Changes or Changing the Model}

The simplest alternative to (2) is to consider a model in log-differences:

$$
\Delta \ln \left(\mathrm{m}_{\mathrm{t}}\right)=6_{0}+6_{1} \Delta \ln \left(\mathrm{y}_{\mathrm{\nu}}\right)+6_{2} \Delta \ln \left(\mathrm{p}_{\mathrm{mt}} / \mathrm{p}_{\mathrm{d}}\right)
$$

where $b_{0}$ is the autonomous growth rate of imports, expected to be zero; $b_{1}$ is the income elasticity, and $B_{2}$ is the price elasticity. ${ }^{17}$ Based on 1890-1992 data, the income elasticities are

\footnotetext{
${ }^{16}$ Note that the estimates based on postwar data alone show that (1) the income elasticity for U.S. imports is significantly greater than the income elasticity of Japanese and Canadian imports and (2) differences among estimated price elasticities are not significant, as found with the fixed-effect model with pooled data (table 2).

${ }^{17}$ Note that equation (3) carries no loss of information about the long-run relation among the level of these variables because, as table 5 shows, there is no long-run relation for the levels of these variables. The inclusion of lags in (3) adds no information for the U.S. and Canadian cases in the sense of having no significant coefficients; for Japan,
} 
Table 5

Cointegration Tests for Imports, Relative Prices, and Expenditures:

Canada, Japan, and United States: 1890-1992

\begin{tabular}{|c|c|c|c|c|}
\hline \multirow{3}{*}{ Null Hypothesis ! } & \multicolumn{4}{|c|}{ Measurement } \\
\hline & \multicolumn{2}{|c|}{ logarithms } & \multicolumn{2}{|c|}{ log-differences } \\
\hline & $\lambda(i)_{\max }$ & $\lambda(r)_{\text {tace }}$ & $\lambda(i)_{\max }$ & $\lambda(r)_{\text {mace }}$ \\
\hline $\begin{array}{l}\text { Canada } \\
\text { Rank } \leq 0\end{array}$ & 8.42 & 12.21 & $40.72 * *$ & $63.27 * *$ \\
\hline Rank $\leq 1$ & 2.72 & 3.79 & $17.18^{*}$ & $22.55^{* *}$ \\
\hline Rank $\leq 2$ & 1.07 & 1.07 & $5.37^{*}$ & $5.37^{*}$ \\
\hline $\begin{array}{l}\text { Japan } \\
\text { Rank } \leq 0\end{array}$ & $24.57 *$ & 25.54 & $44.50^{* *}$ & $78.71 * *$ \\
\hline Rank $\leq 1$ & 0.96 & 0.96 & $26.57^{* *}$ & $34.21 * *$ \\
\hline Rank $\leq 2$ & 0.01 & 0.01 & $7.64 * *$ & $7.64^{* *}$ \\
\hline $\begin{array}{l}\text { U.S. } \\
\text { Rank } \leq 0\end{array}$ & 13.32 & 19.55 & $35.74^{* *}$ & $74.92 * *$ \\
\hline Rank $\leq 1$ & 6.13 & 6.23 & $22.34^{* *}$ & $39.18^{* *}$ \\
\hline Rank $\leq 2$ & 0.10 & 0.10 & $16.84 * *$ & $16.84 * *$ \\
\hline
\end{tabular}

Note: The estimation period is 1894-1992 with data for 1890-1893 reserved for lags. For the system using differenced data, the estimation period is 1895-1992 with data for 1891-1894 reserved for lags; the system includes dummy variables: 1918, 1942, and 1946 for the United States; 1908, 1915 for Canada; 1938, 1942 , 1945 for Japan. $\lambda(i)_{\max }$ is the statistic to test whether the $i$ th eigenvalue is zero; $\lambda(r)_{\text {trace }}$ is the statistic to test whether the sum of $r$ eigenvalues is zero (see Johansen and Juselius (1989)). A "**" denotes statistical significance at the one percent level; both $\lambda(i)_{\max }$ and $\lambda(r)_{\text {trace }}$ include an adjustment for degrees of freedom. The critical values for $\lambda(i)_{\max }$ are $21,14.1$, and 3.8; the critical values for $\lambda(r)_{\text {trace }}$ are $29.7,15.4$, and 3.8. 
significant and vary from 0.8 for Japan to 1.5 for Canada (table 6); the price elasticities vary from an insignificant -0.1 for Japan to a significant -0.4 for Canada. The formulations satisfy price homogeneity but reject the assumed serial independence and zero intercept for Japan.

To evaluate parameter constancy, figure 4 shows the evolution of the 95 percent confidence intervals for the parameter estimates of (3) as the terminal date of the estimation sample increases from 1907 to 1992 in yearly increments. The figure also reports the results for three variants of the Chow test of parameter constancy:

One-step ahead test (denoted as $1 \uparrow$ ): Sequence of F-tests for the hypothesis that the oneperiod ahead forecast error is zero.

Break-Point F-test (denoted as $\mathrm{N} l$ ): Sequence of $\mathrm{F}$-tests for the hypothesis that the out-ofsample forecast errors are jointly equal to zero where the forecast horizon decreases from $\mathrm{N}$ periods to 1 as the estimation sample increases; $\mathrm{N}$ equals 84 .

Forecasts F-test (denoted as $\mathrm{N} 1$ ): Sequence of $\mathrm{F}$-tests for the hypothesis that the out-ofsample forecast errors are jointly equal to zero with the forecast horizon increasing from 1 to $\mathrm{N}^{18}$

The results for Canada suggest that income and price elasticities are constant, though there are some violations of the one-step-ahead Chow test during the 1920s. For Japan, the results reject the assumed constancy of trade elasticities: violations of the Chow tests are persistent and the income elasticity has an upward trend with a widening of the 95 percent confidence band. For the United States, the results support parameter constancy, though there are several failures of the one-step-ahead Chow test during the first half of this century. ${ }^{19}$

additional lags matter in the sense of rejecting the hypothesis that income and relative prices affect imports.

\footnotetext{
18 These tests are implemented in Doornik and Hendry (1994). For the Break-point F-test (N!), the forecast horizon is larger than the initial estimation sample which means that this test is not necessarily optimal (Doornik and Hendry, 1994, p. 329).

19 To examine whether income and prices can be taken as given for parameter estimation in (3), and in the alternative models developed below, I implement the superexogeneity test of Engle, Hendry, and Richard (1983). This procedure involves testing parameter constancy for the equations explaining income and relative prices in terms of
} 
Table 6

Income and Price Effects from Log-Difference Model for Canada, Japan, and United States: 1890-1992 (Standard Errors in Parentheses)

$$
\Delta \ln \left(\mathrm{m}_{\mathrm{t}}\right)=6_{0}+6_{1} \Delta \ln \left(\mathrm{y}_{\mathrm{t}}\right)+6_{2} \Delta \ln \left(\mathrm{p}_{\mathrm{mt}} / \mathrm{p}_{\mathrm{dt}}\right)
$$

\begin{tabular}{|c|c|c|c|}
\hline & Canada & Japan & U.S. \\
\hline Intercept & $\begin{array}{l}-0.158 \\
(0.789)\end{array}$ & $\begin{array}{c}5.087 \\
(2.235)\end{array}$ & $\begin{array}{c}0.004 \\
(0.008)\end{array}$ \\
\hline Income & $\begin{array}{c}1.502 \\
(0.125)\end{array}$ & $\begin{array}{c}0.771 \\
(0.227)\end{array}$ & $\begin{array}{c}1.428 \\
(0.134)\end{array}$ \\
\hline Import Price & $\begin{array}{c}-0.371 \\
(0.142) \\
\end{array}$ & $\begin{array}{c}-0.115 \\
(0.095)\end{array}$ & $\begin{array}{l}-0.208 \\
(0.086)\end{array}$ \\
\hline Price Homogeneity & 1.32 & 1.02 & 1.93 \\
\hline Serial Independence ${ }^{2}$ & 0.95 & $0.02 *$ & 0.07 \\
\hline Homoskedasticity ${ }^{3}$ & 0.20 & 0.83 & 0.79 \\
\hline Explanatory Power ${ }^{4}$ & $0.00 * *$ & $0.00 * *$ & $0.00 * *$ \\
\hline Functional Form ${ }^{5}$ & 0.77 & 0.52 & 0.06 \\
\hline SER & 7.12 & 20.01 & 7.52 \\
\hline $\mathrm{R}^{2}$ & 0.64 & 0.24 & 0.58 \\
\hline
\end{tabular}

Notes: $\mathrm{m}$ is per-capita, real imports; $\mathrm{y}$ is per-capita, real domestic expenditures; $\mathrm{p}_{\mathrm{m}}$ is the tariff-adjusted import price; $\mathrm{p}_{\mathrm{d}}$ is the GNP deflator; the regression includes dummy variables: 1918, 1942, and 1946 for the United States; 1908, 1915 for Canada; 1938, 1942, 1945 for Japan. A* denotes rejection of the null hypothesis at the five percent significance level; ** denotes rejection at the 1 percent significance level.

' $\mathrm{T}$-statistic for the hypothesis that the coefficient for the price of imports, in absolute value, equals the coefficient for the domestic price.

${ }^{2}$ Significance level for rejecting the hypothesis that the coefficients of an AR(2) for the residual are zero using an F-test.

${ }^{3}$ Significance level for rejecting the hypothesis that residuals are homoskedastic using Engle's ARCH test.

${ }^{4}$ Significance level for rejecting the hypothesis that the income and price coefficients are jointly equal to zero using Wald's test.

${ }^{5}$ Significance level for rejecting the choice of functional form using Ramsey's RESET test statistic. 
Figure 4

Recursive Estimates and Parameter Constancy Tests, 1908-1992

Log-Difference Model

One-step ahead F-tests (1D): Sequence of F-tests for the hypothesis that the vector of 1 -step ahead forecast emors is zero; a crossing of the horizontal line denotes a rejection of the hypothesis of parameter constancy at the five-percent level.

Break-point F-tests ( $N \downarrow$ ): Sequence of F-tests for the hypothesis that the vector of $\mathrm{N}$-step ahead forecast errors is zero; the forecast horizon $\mathrm{N}$ decreases from $T-M+1$ to 1 as the estimation sample increases where $T$ is the total number of observations (103) and $M$ is the number of observations reserved as initial conditions (17). Thus for the first sub-sample (1891-1907), the value of $N$ is 84 ; for the second sub-sample (1891-1908), the value of $N$ is 83 , and so on until $N=1$. A crossing of the horizontal line denotes a rejection of the hypothesis of parameter constancy at the five-percent level.

Forecasts F-tests (ND): Sequence of F-tests for the hypothesis that the vector of $\mathrm{N}$-step ahead forecast errors is zero; the forecast horizon $\mathrm{N}$ increases from $M$, the last date of the initial sample (1907), to the current observation $t$ as the estimation sample increases. Thus the value of $\mathrm{N}$ increases from 1 to 84 . A crossing of the horizontal line denotes a rejection of the hypothesis of parameter constancy at the five-percent level.
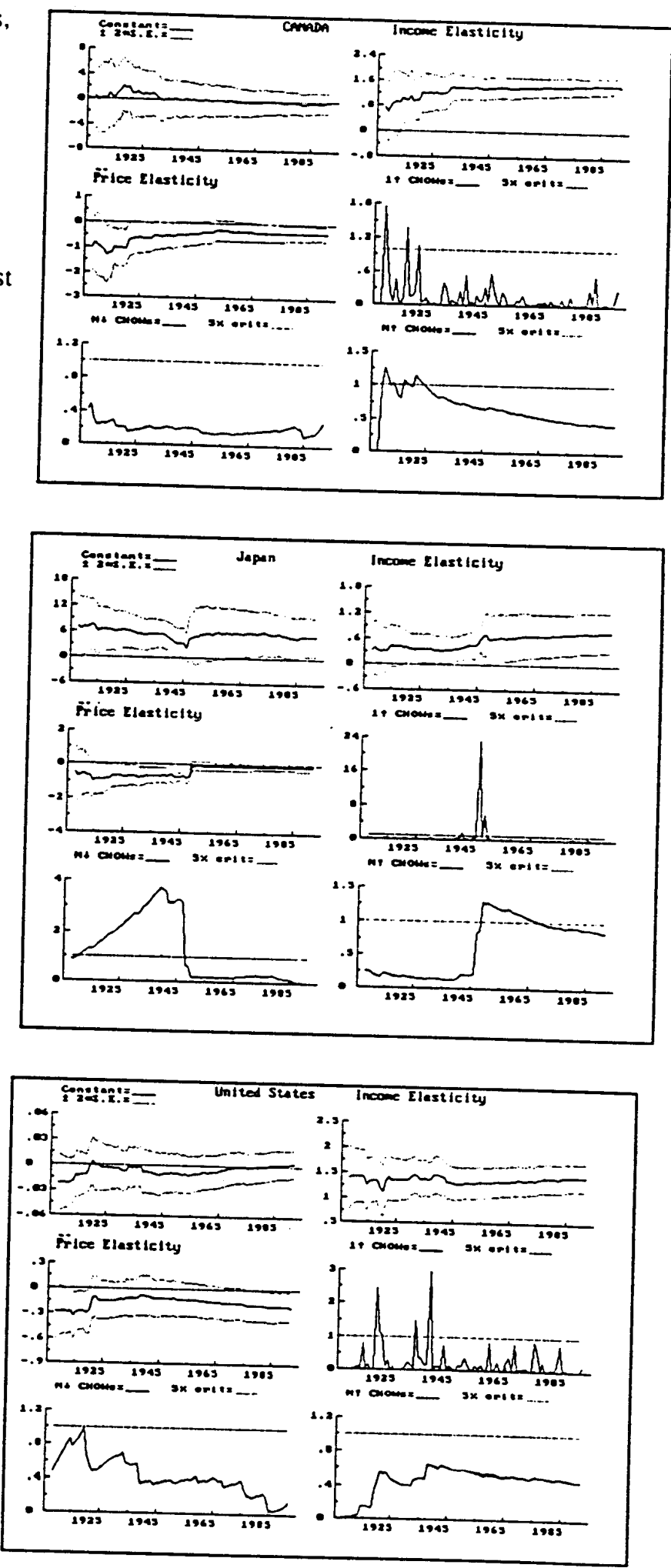
Overall, these results are an improvement over the standard log-linear model, especially for the United States. But the formulations show signs of misspecification and the estimates are not consistent with a key prediction of optimization: if elasticities are constant, then income and price elasticities are one and minus one respectively. ${ }^{20}$ As alternatives to (3), I use models in which individuals determine their spending on domestic and foreign products, $\mathrm{d}$ and $\mathrm{m}$ respectively, by maximizing a utility function $u(d, m)$ subject to $p_{m} m+p_{d} d=p_{y} y{ }^{21}$ The specific formulations I use are the Rotterdam model developed by Barten (1964), Theil (1965), and Barnett (1979) and the Almost Ideal model of Deaton and Muellbauer (1980a).

The Rotterdam model is an approximation to the solution of the first order conditions for maximizing any utility function:

$$
\mathrm{w}_{\mathrm{t}-1} \Delta \ln \left(\mathrm{m}_{\mathrm{t}}\right)=\mu \Delta \ln \left(\mathrm{y}_{\mathrm{t}}\right)+\pi \Delta \ln \left(\mathrm{p}_{\mathrm{t}}\right)+\mathrm{u}_{\mathrm{tt}}, \quad \mu>0 \quad \pi<0,
$$

where $w_{t}$ is the share of imports in expenditures; $\mu$ is the marginal budget share; $\pi$ is the compensated (Slutsky), own-price effect; $p_{t}=\left(p_{m t} / p_{d}\right)$; and $u_{n t}$ is the disturbance induced by approximating the solution of the first-order conditions. I evaluate the quality of this approximation by testing parameter constancy as suggested by Barnett (1984) and Byron (1984). For estimation, (4) includes an intercept, expected to be zero, and dummy variables to control for

exogenous variables. As instruments, I use government purchases and exports, both in real and per-capita terms, along with the lagged own-dependent variable; for Japan I also use currency in circulation to capture the high-inflation episodes. I reject the hypothesis of parameter constancy in the equations for income and relative prices. This result, combined with the finding of parameter constancy in figures 4-6 suggests that treating income and prices as exogenous generates no loss of information for estimating income and price effects, except for Japan in figure 4.

${ }^{20}$ Deaton and Muellbauer (1980b, p.17) show that the log-linear formulation is consistent with adding-up if the income elasticities are equal to one for all goods. This result implies identical patterns of expenditures at all levels of income meaning that expenditures shares are fixed and that the own price elasticity equals minus one.

${ }^{21}$ Reinhart (1995) also uses a utility maximization approach. Alternative formulations could assume that imports are determined by producers who want to maximize the level of production for a given cost (see Kohli 1991). Under this interpretation, "d" would be an aggregate of capital and labor. 
war-related disruptions; an ADF test cannot reject that $w_{t-1} \Delta \ln \left(m_{\imath}\right)$ is stationary.

The estimates of $\mu$ are positive, significant, and vary from 30 percent for Canada to 7 percent for the United States (table 7). Moreover, the results point to a similarity in spending propensities for Japan and the United States whereas the estimates from the log-linear model suggest rather different spending patterns for these two counties. The estimates of $\pi$ are negative, significant, and vary from -6.9 percent for Canada to -1.6 percent for the United States. The results also support the maintained assumptions for the residuals, the choice of functional form, and the joint influence of income and prices on imports; price homogeneity holds for Canada and Japan but not for the United States. Finally, recursive estimation supports the hypothesis of parameter constancy (figure 5) though the price coefficient for Japan has an upward trend and there are instances where the 1-step ahead forecast errors are significantly different from zero.

The Almost Ideal model is the exact solution to the optimization problem when the utility function is approximated with the PIGLOG formulation (Deaton and Muellbauer, 1980a, p. 313):

$$
\Delta \mathrm{w}_{\mathrm{t}}=\delta \Delta \ln \left(\mathrm{y}_{\mathrm{t}}\right)+\gamma \Delta \ln \left(\mathrm{p}_{\mathrm{t}}\right)+\mathrm{u}_{\mathrm{at}},
$$

where $u_{a t}$ is the residual induced by the approximation of the utility function. The coefficients in (5) do not have sign restrictions: if $\delta>0$, then an increase in expenditures raises the share of imports in expenditures; if $\gamma>0$, then an increase in the relative price of imports raises the share of imports in expenditures. ${ }^{22}$ For estimation, (5) includes an intercept and dummy variables to control for war-related disruptions; an ADF test cannot reject that $\Delta \mathrm{w}_{\mathrm{t}}$ is stationary.

The estimates of $\delta$ are positive and significant except for Japan, which is negative (table 8). A negative $\delta$ means that the share of imports declines as expenditures increase, a result consistent

\footnotetext{
22 The solution of the Almost Ideal System is $w_{t}=\delta \ln \left(y_{\nu}\right)+\gamma \ln \left(p_{v}\right)$ but this formulation fails cointegration tests. Thus I use equation (17) of Deaton and Muellbauer (1980a, p.317). For an early application of this system to studying international trade see Winters (1984).
} 
Table 7

Income and Price Effects from Rotterdam Model for Canada, Japan, and United States: 1890-1992

(Standard Errors in Parentheses)

$$
\mathrm{w}_{\mathrm{t}-1} \Delta \ln \left(\mathrm{m}_{\mathrm{l}}\right)=\omega+\mu \Delta \ln \left(\mathrm{y}_{\mathrm{l}}\right)+\pi \Delta \ln \left(\mathrm{p}_{\mathrm{v}}\right)
$$

\begin{tabular}{|c|c|c|c|}
\hline & Canada & Japan & U.S. \\
\hline Intercept & $\begin{array}{c}-0.086 \\
(0.172)\end{array}$ & $\begin{array}{c}0.403 \\
(0.191)\end{array}$ & $\begin{array}{c}0.022 \\
(0.041)\end{array}$ \\
\hline Income & $\begin{array}{c}0.297 \\
(0.027)\end{array}$ & $\begin{array}{c}0.098 \\
(0.019)\end{array}$ & $\begin{array}{r}0.066 \\
(0.007)\end{array}$ \\
\hline Import Price & $\begin{array}{c}-0.069 \\
(0.031) \\
\end{array}$ & $\begin{array}{r}-0.019 \\
(0.008) \\
\end{array}$ & $\begin{array}{l}-0.016 \\
(0.004) \\
\end{array}$ \\
\hline Price Homogeneity ${ }^{1}$ & 1.18 & 0.95 & $2.87^{*}$ \\
\hline Serial Independence ${ }^{2}$ & 0.95 & 0.67 & 0.06 \\
\hline Homoskedasticity ${ }^{3}$ & 0.14 & 0.41 & 0.29 \\
\hline Functional Form ${ }^{4}$ & 0.80 & 0.10 & 0.19 \\
\hline Explanatory Power & $0.00 * *$ & $0.00 * *$ & $0.00 * *$ \\
\hline SER & 1.55 & 1.71 & 0.38 \\
\hline $\mathrm{R}^{2}$ & 0.62 & 0.36 & 0.53 \\
\hline
\end{tabular}

Notes: $m$ is per-capita, real imports; $y$ is per-capita, real domestic expenditures; $p$ is the ratio of the tariff-adjusted import price to the GNP deflator; the regression includes dummy variables: 1918, 1942, and 1946 for the United States; 1908, 1915 for Canada; 1938, 1942, 1945 for Japan. A* denotes rejection of the null hypothesis at the five percent significance level; $* *$ denotes rejection at the 1 percent significance level.

${ }^{1} \mathrm{~T}$-statistic for the hypothesis that the coefficient for the price of imports, in absolute value, equals the coefficient for the domestic price.

${ }^{2}$ Significance level for rejecting the hypothesis that the coefficients of an AR(2) for the residual are zero using an F-test.

${ }^{3}$ Significance level for rejecting the hypothesis that residuals are homoskedastic using Engle's ARCH test.

${ }^{4}$ Significance level for rejecting the choice of functional form using Ramsey's RESET test statistic.

${ }^{5}$ Significance level for rejecting the hypothesis that the income and price coefficients are jointly equal to zero using Wald's test. 
Figure 5

Recursive Estimates and Parameter Constancy Tests, 1908-1992

Rotterdam Model

One-step ahead F-tests (1T): Sequence of F-tests for the hypothesis that the vector of 1-step ahead forecast errors is zero; a crossing of the horizontal line denotes a rejection of the hypothesis of parameter constancy at the five-percent level.

Break-point F-tests $(N \downarrow)$ : Sequence of F-tests for the hypothesis that the vector of $\mathrm{N}$-step ahead forecast errors is zero; the forecast horizon $\mathrm{N}$ decreases from $\mathrm{T}-\mathrm{M}+1$ to 1 as the estimation sample increases where $T$ is the total number of observations (103) and $M$ is the number of observations reserved as initial conditions (17). Thus for the first sub-sample (1891-1907), the value of $\mathrm{N}$ is 84 ; for the second sub-sample (1891-1908), the value of $N$ is 83 , and so on until $N=1$. A crossing of the horizontal line denotes a rejection of the hypothesis of parameter constancy at the five-percent level.

Forecasts F-tests (NT): Sequence of F-tests for the hypothesis that the vector of $\mathrm{N}$-step ahead forecast errors is zero; the forecast horizon $\mathrm{N}$ increases from $\mathrm{M}$, the last date of the initial sample (1907), to the current observation $t$ as the estimation sample increases. Thus the value of $\mathrm{N}$ increases from 1 to 84 . A crossing of the horizontal line denotes a rejection of the hypothesis of parameter constancy at the five-percent level.
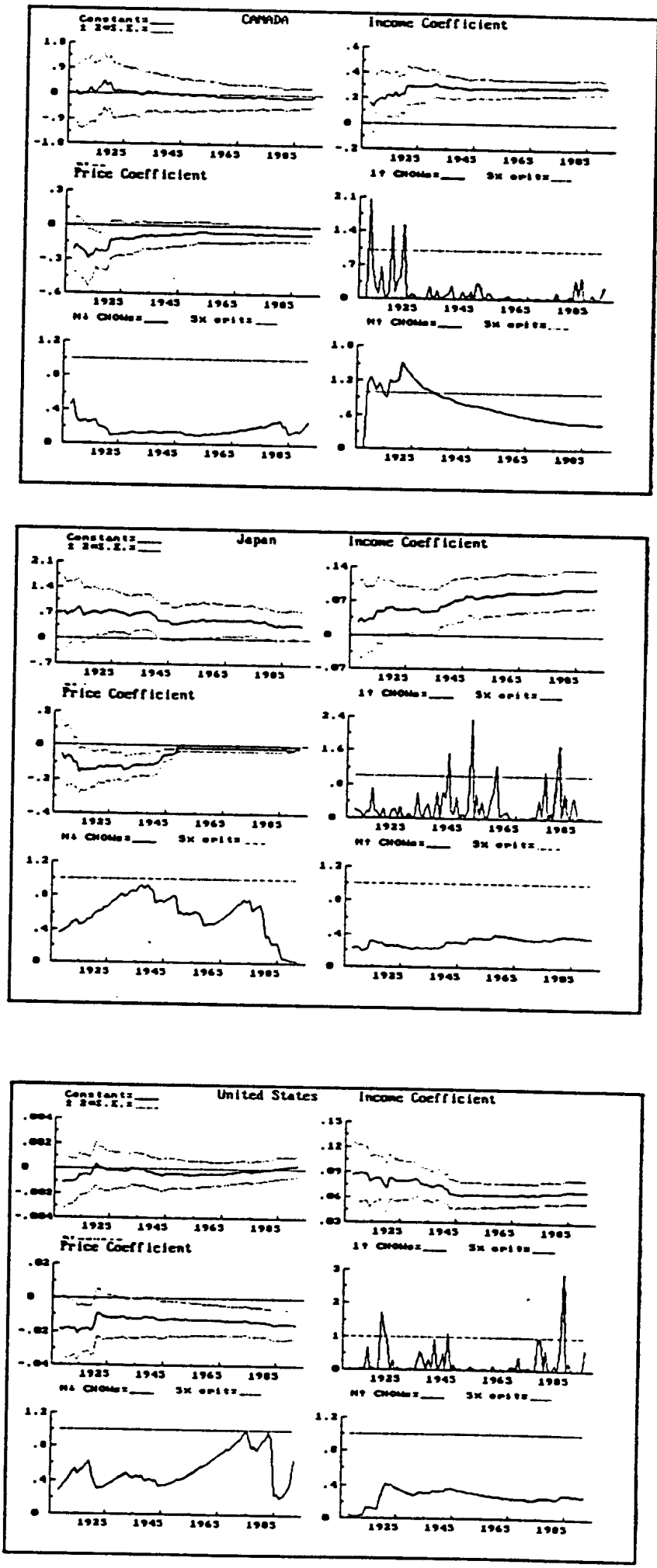
with the importance of raw materials in Japanese imports. The estimates of $\gamma$ are positive and significant meaning that increases in the relative price of imports raise the share of imports in expenditures--that is, imports are price inelastic. The test results reject price homogeneity for the U.S. formulation and the choice of functional form for both Canada and the United States; Chow tests support parameter constancy (figure 6), but the income coefficient for Japan shows an upward trend and there are instances where the 1-step ahead forecast errors are significantly different from zero.

\section{The Illusion of Constancies}

A key feature of optimization-based models is that their income and price elasticities respond to changes in the composition of expenditures, though the choice of optimizing setup affects the elasticity estimate. Specifically, the income elasticities are $\mu / \mathrm{w}_{\mathrm{t}-1}$ for the Rotterdam model and $\left(1+\delta / w_{t}\right)$ for the Almost Ideal model; the compensated own-price elasticities are $\pi / w_{t-1}$ for the Rotterdam and $\left(-1+w_{t}+\gamma / w_{v}\right)$ for the Almost Ideal model. For these elasticities to be constant either $w_{t}$ must be constant, which contradicts the data (figure 2), or parameter changes must offset exactly changes in $w_{t}$, which is not supported by the evidence on parameter constancy (figures 5 6). Thus elasticities are not, in general, constant and the remaining question is how large are their fluctuations relative to the estimates of the log-difference model..$^{23}$

According to the evidence, income elasticities are positive and fluctuate over time (figure 7). ${ }^{24}$ These fluctuations are not the result of unspecified structural changes but instead the result of

${ }^{23}$ See Green and Alston (1990) for the elasticities of the Almost Ideal system.

${ }^{24}$ The sole instance of a negative income elasticity comes from the Almost Ideal model for Japan in 1945 given that the income coefficient is negative and the share of imports is almost zero. 
Table 8

Income and Price Effects from Almost Ideal Model for Canada, Japan, and United States: 1890-1992

(Standard Errors in Parentheses)

$$
\Delta \mathrm{w}_{\mathrm{t}}=\mathrm{v}+\delta \Delta \ln \left(\mathrm{y}_{\mathrm{v}}\right)+\gamma \Delta \ln \left(\mathrm{p}_{\mathrm{v}}\right)
$$

\begin{tabular}{|c|c|c|c|}
\hline & Canada & Japan & U.S. \\
\hline Intercept & $\begin{array}{c}-0.151 \\
(0.176)\end{array}$ & $\begin{array}{c}0.302 \\
(0.193)\end{array}$ & $\begin{array}{c}0.015 \\
(0.038)\end{array}$ \\
\hline Income & $\begin{array}{c}0.106 \\
(0.028)\end{array}$ & $\begin{array}{l}-0.051 \\
(0.019)\end{array}$ & $\begin{array}{c}0.015 \\
(0.006)\end{array}$ \\
\hline Import Price & $\begin{array}{c}0.129 \\
(0.032)\end{array}$ & $\begin{array}{c}0.036 \\
(0.008)\end{array}$ & $\begin{array}{c}0.039 \\
(0.004)\end{array}$ \\
\hline Price Homogeneity & 1.47 & 1.20 & $2.44^{*}$ \\
\hline Serial Independence ${ }^{2}$ & 0.91 & 0.69 & 0.12 \\
\hline Homoskedasticity ${ }^{3}$ & $0.00 * *$ & 0.17 & 0.30 \\
\hline Functional Form ${ }^{4}$ & $0.05^{*}$ & 0.51 & $0.00^{* *}$ \\
\hline Explanatory Power & $0.00^{* *}$ & $0.00^{* *}$ & $0.00 * *$ \\
\hline SER & 1.58 & 1.73 & 0.36 \\
\hline $\mathrm{R}^{2}$ & 0.41 & 0.33 & 0.57 \\
\hline
\end{tabular}

Notes: $m$ is per-capita, real imports; $y$ is per-capita, real domestic expenditures; $p$ is the ratio of the tariff-adjusted import price to the GNP deflator; the regression includes dummy variables: 1918, 1942, and 1946 for the United States; 1908 , 1915 for Canada; 1938, 1942, 1945 for Japan. A * denotes rejection of the null hypothesis at the five percent significance level; ${ }^{* *}$ denotes rejection at the 1 percent significance level.

${ }^{1} \mathrm{~T}$-statistic for the hypothesis that the coefficient for the price of imports, in absolute value, equals the coefficient for the domestic price.

${ }^{2}$ Significance level for rejecting the hypothesis that the coefficients of an AR(2) for the residual are zero using an F-test.

${ }^{3}$ Significance level for rejecting the hypothesis that residuals are homoskedastic using Engle's ARCH test.

${ }^{4}$ Significance level for rejecting the choice of functional form using Ramsey's RESET test statistic.

${ }^{5}$ Significance level for rejecting the hypothesis that the income and price coefficients are jointly equal to zero using Wald's test. 
Figure 6

Recursive Estimates and Parameter Constancy Tests:1908-1992

Almost Ideal Model

Qne-step ahead F-tests (1 1 ): Sequence of F-tests for the hypothesis that the vector of 1-step ahead forecast errors is zero; a crossing of the horizontal line denotes a rejection of the hypothesis of parameter constancy at the five-percent level.

Break-point F-tests (N $\downarrow$ ): Sequence of F-tests for the hypothesis that the vector of $\mathrm{N}$-step ahead forecast errors is zero; the forecast horizon $\mathrm{N}$ decreases from $\mathrm{T}-\mathrm{M}+1$ to 1 as the estimation sample increases where $\mathrm{T}$ is the total number of observations (103) and $M$ is the number of observations reserved as initial conditions (17). Thus for the first sub-sample (1891-1907), the value of $\mathrm{N}$ is 84 ; for the second sub-sample (1891-1908), the value of $N$ is 83 , and so on until $N=1$. A crossing of the horizontal line denotes a rejection of the hypothesis of parameter constancy at the five-percent level.

Forecasts F-tests (ND): Sequence of F-tests for the hypothesis that the vector of $\mathrm{N}$-step ahead forecast errors is zero; the forecast horizon $\mathrm{N}$ increases from $M$, the last date of the initial sample (1907), to the current observation $t$ as the estimation sample increases. Thus the value of $\mathrm{N}$ increases from 1 to 84. A crossing of the horizontal line denotes a rejection of the hypothesis of parameter constancy at the five-percent level.
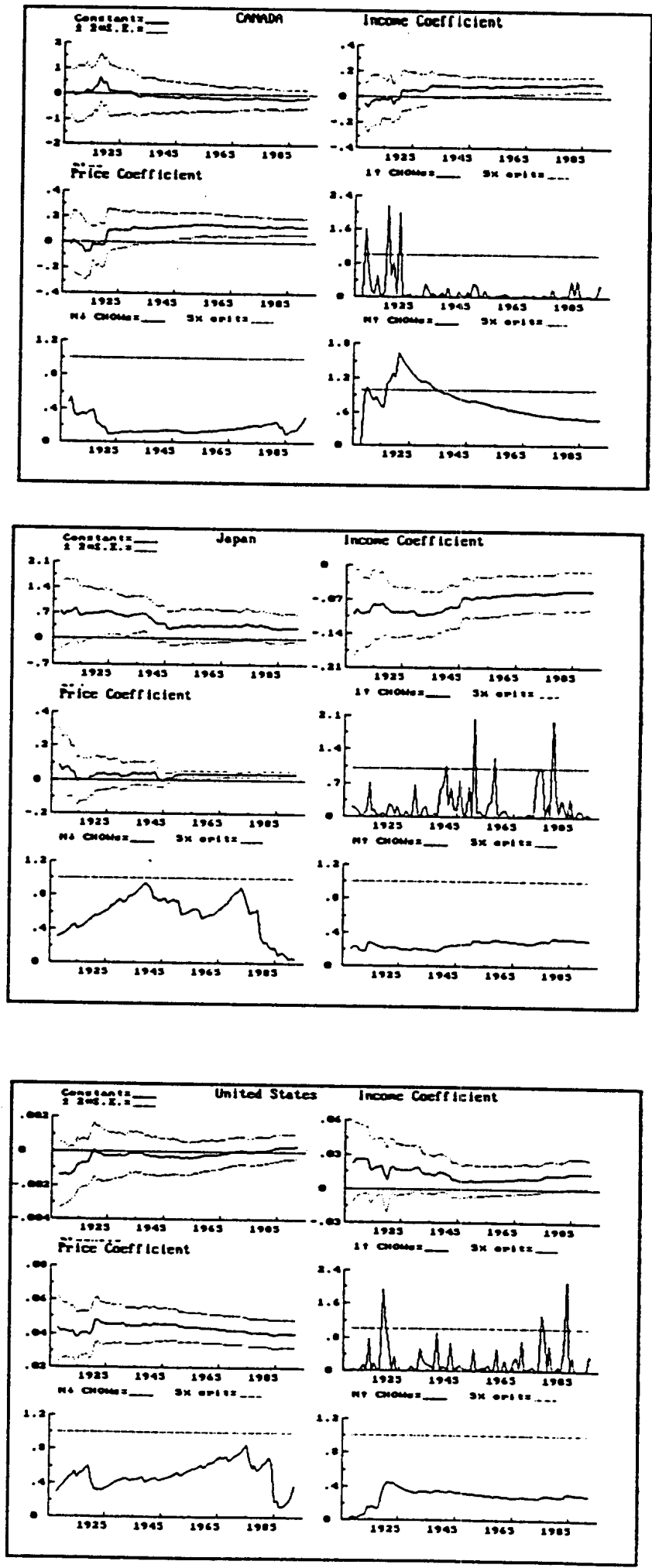
changes in the share of imports. For example, the estimates for the Rotterdam model imply that, from 1960 to 1992 , the estimated income elasticity declines from 2.1 to 1.4 for Canada and from 2.5 to 0.8 for the United States; for Japan the estimated elasticity fluctuates between 0.5 and 1.5 with no clear pattern. The estimates from the Almost Ideal model also show declining income elasticities for Canada and the United States though the declines are smaller than those of the Rotterdam model.

Note that the estimated income elasticities for Japan predicted by the Rotterdam and Almost Ideal formulations fluctuate in opposite directions. This pattern reflects the negative income coefficient for the Almost Ideal formulation which induces a direct association between the share of imports and the income elasticity whereas the Rotterdam model embodies an inverse association; ${ }^{25}$ this finding underscores the sensitivity of elasticities to the choice of optimizing setup. Finally, and in contrast to the literature summarized in table 1 , the three models give similar estimates for the post Bretton-Woods period.

The compensated price elasticities reveal four features of interest. First, they are not always negative. Specifically, the Almost Ideal model gives positive price elasticities for Canada and the United States, the two countries for which the test of functional form rejects the Almost Ideal formulation (table 8). Second, their fluctuations are smaller than those exhibited by income elasticities. Third, the estimates from the three models are similar during 1973-1992; otherwise the models show noticeable differences in elasticity estimates. Fourth, the evidence is not wholly supportive of Krugman's delinking hypothesis: Though price responsiveness declines in the post 1973 period, the decline begins in the mid-1960s when nominal parities were fixed.

\footnotetext{
${ }^{25}$ The derivative of the income elasticity for the Almost Ideal model with respect to the import share is $-\delta / w_{t}^{2}$ which is positive if $\delta<0$.
} 
FIGURE 7: Elasticities for Imports, 1890-1992
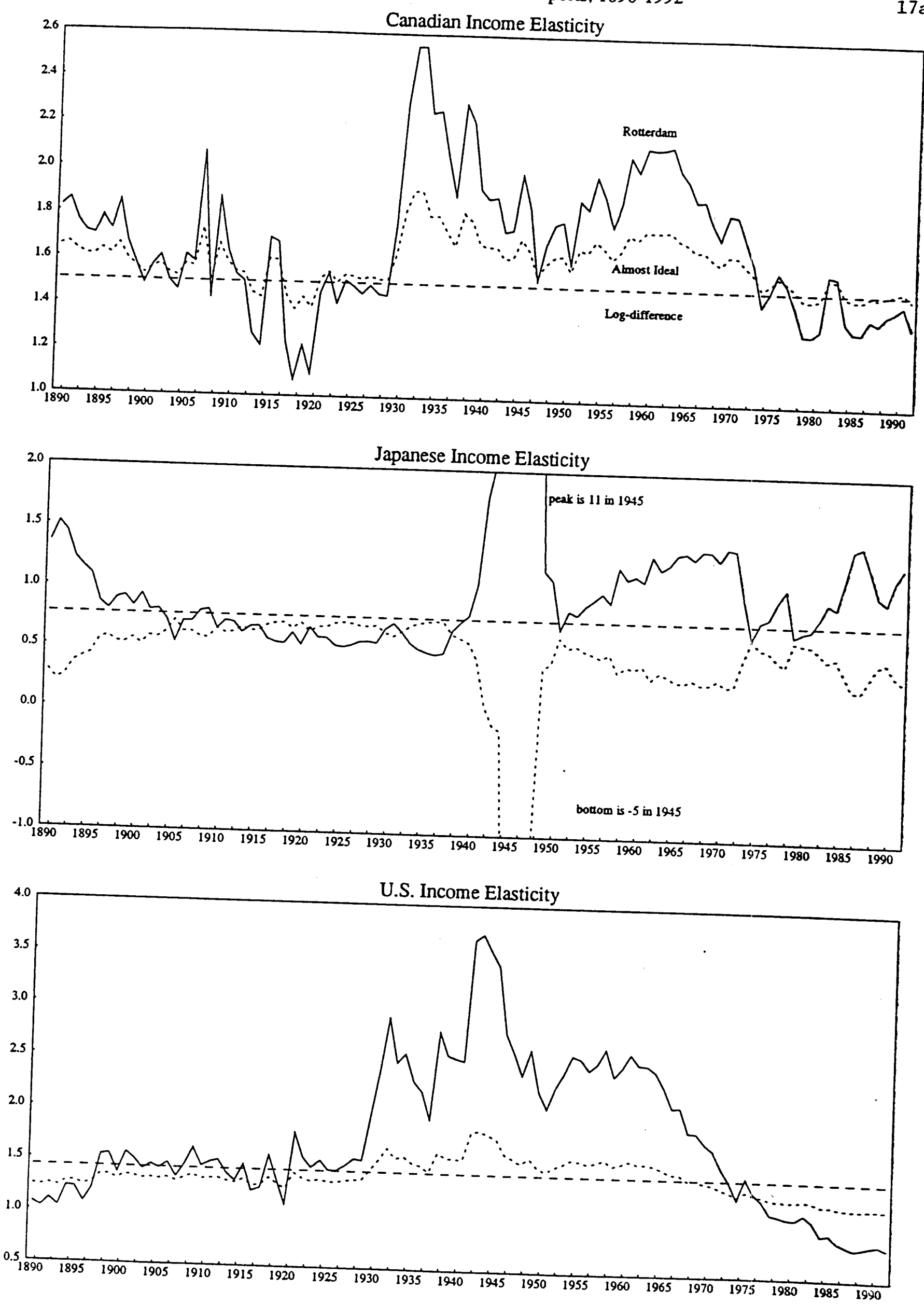

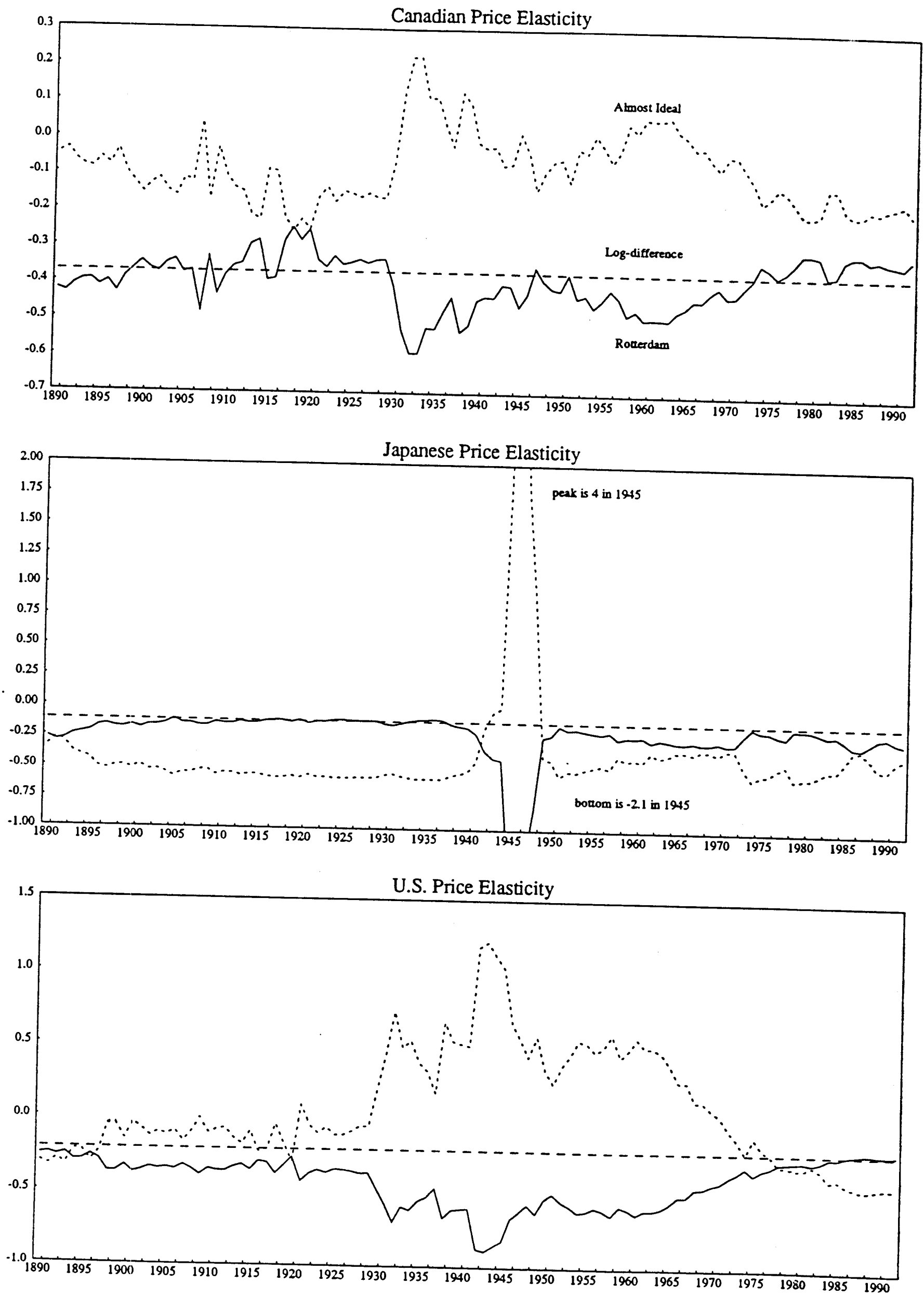
From a practical standpoint, the elasticity estimates from the optimization-based models portray imports as being less responsive to prices and income than the estimates found in the literature. Indeed, the estimated price elasticities are (in absolute value) substantially below one, below the estimates of the log-linear model based on postwar data (table 4), and below the estimates found in the literature (tables 1-2). The estimated income elasticity for the United States from the Rotterdam model since the 1970s is below the corresponding estimate for the log-linear model based on postwar data $(3.3$, table 4$)$, below the prototype estimate generated by the fixedeffect model (2.1, table 2), and below the mean of the literature's estimates (1.9, table 1). Thus reliance on the log-linear model overstates by a significant margin the response of the U.S. trade deficit to changes in U.S. economic activity.

\section{Conclusions}

Treating elasticities as constant parameters and estimating them with sub-samples of the postwar period are two features unifying fifty years of econometric work on imports for Canada, Japan, and the United States. These two features do not provide, however, an adequate understanding of the role of income and prices in determining these imports: the dispersion of elasticities is substantial and the estimates are unstable, two features that call into question the view that income and prices affect imports. I argue that changes in the composition of expenditures are responsible for the instability of elasticities and that characterizing the role of income and relative prices in determining imports needs as much information as possible on the evolution of this composition.

I estimate the elasticities of the log-linear model with a sample covering a century and find that Canadian imports are not price responsive and that U.S. imports are not affected by either relative prices or income, which is in contrast to the results found in the literature. To address this 
puzzle, I consider alternatives formulations that eliminate the restrictions of the log-linear formulation. Though the results are not trouble free, the alternative models explain the whole evolution of imports, not just postwar sub-samples, and support a robust role for income and prices decade after decade.

Incorporating the whole evolution of imports need not be central to estimating income and price effects if the associated estimates are used for short-term forecasting. But this practice confuses understanding with predicting, contributes to the large dispersion of estimates found in the literature, and leaves unanswered a key question: If the log-linear model cannot explain imports in the past, why should it be trusted to explain imports in the future? Claiming victory means allowing elasticities to change. 
Appendix A: Chronology of Elasticity Estimates for Selected Studies of Imports

This appendix lists papers reporting econometric estimates of trade elasticities for single-equation models of aggregate import demand for Canada, Japan, and the United States. By design, the appendix excludes studies examining the structure of trade on the basis of factor content or using non-parametric methods; papers reporting econometric estimates for relatively small components of imports are not included in this survey. Stern et al. (1976), Thursby and Thursby (1984), Goldstein and Khan (1985), Kohli (1991), and Marquez (1992) provide reviews of the literature that are not limited by these considerations. Table Al shows the studies used in this paper and their main characteristics which are listed below.

Estimator:

ILS: Indirect Least Squares.

NLS: Nonlinear Least Squares.

OLS: Ordinary Least Squares.

Price Behavior: $\quad$ Exogenous: Prices are taken as given for estimation.

Endogenous: Prices are not taken as given for estimation.

Dynamic Structure: $\quad$ DL: Distributed lags.

ECM: Error-correction model.

Koyck: Lagged dependent variable is the only lag.

PDL: Polynomial distributed lag.

RL: Rational lag.

Shiller: Shiller lags.

Static: No allowance for lags.

Homogeneity: $\quad$ Yes: Estimating equation maintains homogeneity of degree zero in prices.

No: In the absence of homogeneity, the price elasticity corresponds to the estimated coefficient on the foreign-price, whether or not it is combined with an exchange-rate term.

Domestic Price GDP/GNP: GDP/GNP price deflator.

$\mathrm{CPI}$ : Consumer price index.

WPI: Wholesale (or producer) price index.

Tradeable: Price index for domestic product competing with imports.

Price Data: $\quad$ Multilateral: Price data do not differentiate across trading partners.

Bilateral: Price data differentiate across trading partners.

Data Frequency: $\quad$ A: Annual; Q: Quarterly; S: Semi-annual.

Trade Data: $\quad$ Total: Measure of imports includes oil imports.

Non-oil: Measure of imports excludes oil imports.

Author's aggregation of individual elasticities using trade shares.

Author's imputation of standard error. If the study does not report standard errors but indicates that the elasticities are significant, then I impute a t-statistic of 2 . If the study does not give a sense of how significant are the elasticities, then $\bigvee$ impute a tstatistic of one. 
Table Al

Chronology of Elasticity Estimates: Selected Studies for Canada, Japan, the United States

\begin{tabular}{|c|c|c|c|c|c|c|}
\hline \multirow[t]{2}{*}{ Study/Trade Data } & \multirow{2}{*}{$\begin{array}{l}\text { Estimator/ } \\
\text { Price } \\
\text { Behavior /\# } \\
\end{array}$} & \multirow{2}{*}{$\begin{array}{l}\text { Dyn. Struct; } \\
\text { Homogeneity; } \\
\text { Domestic Pr. }\end{array}$} & \multirow{2}{*}{$\begin{array}{l}\text { Price Data/ } \\
\text { Frequency; } \\
\text { Sample } \\
\end{array}$} & \multirow[t]{2}{*}{ Country } & \multicolumn{2}{|c|}{ Elasticity Estimates } \\
\hline & & & & & Income (t-stat) & Price (t-stat) \\
\hline $\begin{array}{l}\text { Chang }(1946 \text {,table } 4) / \\
\text { Total }\end{array}$ & $\begin{array}{l}\text { OLS/Exog. } \\
1,34,53\end{array}$ & $\begin{array}{l}\text { Static; Yes } \\
\text { GDP }\end{array}$ & $\begin{array}{l}\text { Multilateral/ } \\
\text { A;1924-38 }\end{array}$ & $\begin{array}{l}\text { U.S. } \\
\text { Canada } \\
\text { Japan } \\
\end{array}$ & $\begin{array}{l}1.27(1.00 \mathrm{i}) \\
1.75(1.00 \mathrm{i}) \\
1.35(1.00 \mathrm{i}) \\
\end{array}$ & $\begin{array}{l}-0.97(-1.00 \mathrm{i}) \\
-1.34(-1.00 \mathrm{i}) \\
-0.47(-1.00 \mathrm{i}) \\
\end{array}$ \\
\hline $\begin{array}{l}\text { Krause }(1962, \text { table } 3) / \\
\text { Nonoil }\end{array}$ & $\begin{array}{l}\text { OLS/Exog. } \\
2 \\
\end{array}$ & $\begin{array}{l}\text { Static;Yes; } \\
\text { Tradeable }\end{array}$ & $\begin{array}{l}\text { Cross-sec.l } \\
\text { A;1947-58 } \\
\end{array}$ & U.S. & $1.00(1.00 \mathrm{i})$ & $-1.98(-4.13)$ \\
\hline $\begin{array}{l}\text { Kreinin }(1967, \text { table } 3) / \\
\text { Total }\end{array}$ & $\begin{array}{l}\text { OLS/Exog. } \\
3\end{array}$ & $\begin{array}{l}\text { DL;Yes; } \\
\text { WPI } \\
\end{array}$ & $\begin{array}{l}\text { Multilateral/ } \\
\text { A; 1954-64 }\end{array}$ & U.S. & $1.27(16.3)$ & $-1.11(-6.94)$ \\
\hline $\begin{array}{l}\text { Hein (1968,pp. } 705 \& \\
709) / \text { Total. }\end{array}$ & $\begin{array}{l}\text { OLS/Exog. } \\
4,35\end{array}$ & $\begin{array}{l}\text { DL; Yes; } \\
\mathrm{CPI}\end{array}$ & $\begin{array}{l}\text { Multilateral/ } \\
\mathrm{A} ; 1951-65 \\
\end{array}$ & $\begin{array}{l}\text { U.S. } \\
\text { Canada } \\
\end{array}$ & $\begin{array}{l}1.21(7.56) \\
0.44(6.55) \\
\end{array}$ & $\begin{array}{l}-0.62(-3.10) \\
-0.73(-4.58) \\
\end{array}$ \\
\hline $\begin{array}{l}\text { Houthakker and Magee } \\
(1969, \text { table } 1) / \text { Total }\end{array}$ & $\begin{array}{l}\text { OLS/Exog. } \\
5,36,54\end{array}$ & $\begin{array}{l}\text { Static;Yes; } \\
\text { WPI }\end{array}$ & $\begin{array}{l}\text { Multilateral/ } \\
\text { A;1951-66 }\end{array}$ & $\begin{array}{l}\text { U.S. } \\
\text { Canada } \\
\text { Japan } \\
\end{array}$ & $\begin{array}{l}1.51(12.1) \\
1.20(16.31) \\
1.23(13.06) \\
\end{array}$ & $\begin{array}{l}-0.54(-1.60) \\
-1.46(-2.67) \\
-0.72(-2.40) \\
\end{array}$ \\
\hline $\begin{array}{l}\text { Magee (1972,pp. 8-9)/ } \\
\text { Nonoil }\end{array}$ & $\begin{array}{l}\text { OLS/Exog. } \\
6\end{array}$ & $\begin{array}{l}\text { Static;Yes; } \\
\text { WPI } \\
\end{array}$ & $\begin{array}{l}\text { Bilateral/ } \\
\text { A;1951-69 } \\
\end{array}$ & U.S. & $1.54(1.00 \mathrm{i})$ & $-1.26(-1.00 \mathrm{i})$ \\
\hline $\begin{array}{l}\text { Taplin (1973, tables 1- } \\
\text { 2)/ Total }\end{array}$ & $\begin{array}{l}\text { OLS/Exog. } \\
7,37,55\end{array}$ & $\begin{array}{l}\text { Static;Yes; } \\
\text { WPI }\end{array}$ & $\begin{array}{l}\text { Multilateral/ } \\
\text { A;1953-70 }\end{array}$ & $\begin{array}{l}\text { U.S. } \\
\text { Canada } \\
\text { Japan } \\
\end{array}$ & $\begin{array}{l}1.81(2.00 \mathrm{i}) \\
1.18(2.00 \mathrm{i}) \\
1.12(2.00 \mathrm{i}) \\
\end{array}$ & $\begin{array}{l}-1.05(-2.00 \mathrm{i}) \\
-1.59(-2.00 \mathrm{i}) \\
-0.81(-1.00 \mathrm{i}) \\
\end{array}$ \\
\hline $\begin{array}{l}\text { Clark (1974,pp.220-8)/ } \\
\text { Nonoil }\end{array}$ & $\begin{array}{l}\text { OLS/Exog. } \\
8 \\
\end{array}$ & $\begin{array}{l}\text { PDL;Yes; } \\
\text { WPI } \\
\end{array}$ & $\begin{array}{l}\text { Multilateral/ } \\
\text { Q;1963-73 }\end{array}$ & U.S. & $2.79(51.2)^{*}$ & $-3.72(-7.40)^{*}$ \\
\hline $\begin{array}{l}\text { Miller and Fratiani } \\
(1974, \text { table 1)/ Total }\end{array}$ & $\begin{array}{l}\text { OLS/Exog. } \\
9\end{array}$ & $\begin{array}{l}\text { Koyck; Yes; } \\
\text { GNP }\end{array}$ & $\begin{array}{l}\text { Multilateral/ } \\
\text { Q;1956-72 }\end{array}$ & U.S. & $1.96(2.00 \mathrm{i})$ & $-0.73(-1.00 \mathrm{i})$ \\
\hline $\begin{array}{l}\text { Ahluwalia and } \\
\text { Hernandez-Cata (1975, } \\
\text { table 1)/ Nonoil }\end{array}$ & $\begin{array}{l}\text { ILS/Endog. } \\
10\end{array}$ & $\begin{array}{l}\text { DL;No; } \\
\text { WPI }\end{array}$ & $\begin{array}{l}\text { Multilateral/ } \\
\text { Q;1960-73 }\end{array}$ & U.S. & $1.33(14.77)$ & $-1.65(-5.64)$ \\
\hline $\begin{array}{l}\text { Khan and Ross (1975, } \\
\text { table 1)/ Total }\end{array}$ & $\begin{array}{l}\text { OLS/Exog. } \\
11,38,56\end{array}$ & $\begin{array}{l}\text { Static;Yes } \\
\text { WPI }\end{array}$ & $\begin{array}{l}\text { Multilateral/ } \\
S ; 1960-72\end{array}$ & $\begin{array}{l}\text { U.S. } \\
\text { Canada } \\
\text { Japan } \\
\end{array}$ & $\begin{array}{l}2.47(4.73) \\
1.35(2.46) \\
1.23(3.34) \\
\end{array}$ & $\begin{array}{l}-1.00(-1.90) \\
-2.13(-6.47) \\
+0.15(0.44) \\
\end{array}$ \\
\hline $\begin{array}{l}\text { Yadav }(1975, \text { table } 2) / \\
\text { Total }\end{array}$ & $\begin{array}{l}\text { OLS/Exog. } \\
48 \\
\end{array}$ & $\begin{array}{l}\text { Koyck;Yes; } \\
\text { WPI } \\
\end{array}$ & $\begin{array}{l}\text { Multilateral/ } \\
\text { Q; 1956-72 } \\
\end{array}$ & Canada & $1.11(3.70)$ & $-2.49(-2.71)$ \\
\hline $\begin{array}{l}\text { Hooper }(1976, \text { table } 2) / \\
\text { Nonoil }\end{array}$ & $\begin{array}{l}\text { OLS/Exog. } \\
12\end{array}$ & $\begin{array}{l}\text { DL; Yes; } \\
\text { Tradeable }\end{array}$ & $\begin{array}{l}\text { Multilateral/ } \\
Q ; 1956-75 \\
\end{array}$ & U.S. & $1.06(2.00)$ & $-0.54(-5.32)$ \\
\hline $\begin{array}{l}\text { Murray and Ginman } \\
(1976, \text { tables } 1,2) / \\
\text { Total }\end{array}$ & $\begin{array}{l}\text { OLS/Exog. } \\
13,47\end{array}$ & $\begin{array}{l}\text { Static; No; } \\
\text { GDP:Canada } \\
\text { WPI:U.S. } \\
\end{array}$ & $\begin{array}{l}\text { Multilateral/ } \\
\text { Q;1961-68 }\end{array}$ & $\begin{array}{l}\text { U.S. } \\
\text { Canada }\end{array}$ & $\begin{array}{l}0.96(3.80) \\
0.51(4.70)\end{array}$ & $\begin{array}{l}-1.05(-1.60) \\
-0.72(-5.50)\end{array}$ \\
\hline $\begin{array}{l}\text { Khan and Ross (1977, } \\
\text { table 2)/ Total }\end{array}$ & $\begin{array}{l}\text { OLS/Exog. } \\
14,39,57\end{array}$ & $\begin{array}{l}\text { Koyck; Yes; } \\
\text { WPI }\end{array}$ & $\begin{array}{l}\text { Multilateral/ } \\
\text { Q;1960-72 }\end{array}$ & $\begin{array}{l}\text { U.S. } \\
\text { Canada } \\
\text { Japan }\end{array}$ & $\begin{array}{l}1.42(5.68) \\
1.66(7.56) \\
0.68(2.50)\end{array}$ & $\begin{array}{l}-2.16(-2.00) \\
-0.99(-1.70) \\
-3.37(-2.07)\end{array}$ \\
\hline
\end{tabular}


Table Al (continued)

Chronology of Elasticity Estimates: Selected Studies for Canada, Japan, and the United States

\begin{tabular}{|c|c|c|c|c|c|c|}
\hline \multirow[t]{2}{*}{ Study/ Trade Data } & \multirow{2}{*}{$\begin{array}{l}\text { Estimator/ } \\
\text { Price } \\
\text { Behavior/\# } \\
\end{array}$} & \multirow{2}{*}{$\begin{array}{l}\text { Dyn.Struct; } \\
\text { Homogeneity; } \\
\text { Domestic Pr. }\end{array}$} & \multirow{2}{*}{$\begin{array}{l}\text { Price Data/ } \\
\text { Frequency; } \\
\text { Sample } \\
\end{array}$} & \multirow[t]{2}{*}{ Country } & \multicolumn{2}{|c|}{ Elasticity Estimates } \\
\hline & & & & & Income (t-stat) & Price (t-stat) \\
\hline $\begin{array}{l}\text { Deppler and Ripley } \\
(1978, \text { tables } 11,13 \text {, } \\
14 \text {, and } 16) / \text { Nonoil }\end{array}$ & $\begin{array}{l}\text { OLS/Exog. } \\
15,40,58\end{array}$ & $\begin{array}{l}\text { DL;Yes; } \\
\text { Product } \\
\text { specific }\end{array}$ & $\begin{array}{l}\text { Multilateral/ } \\
\text { S;1964-76 }\end{array}$ & $\begin{array}{l}\text { U.S. } \\
\text { Canada } \\
\text { Japan } \\
\end{array}$ & $\begin{array}{l}1.39(2.24)^{*} \\
1.37(4.01)^{*} \\
1.09(5.93)^{*} \\
\end{array}$ & $\begin{array}{l}-1.45(-6.00)^{*} \\
-0.75(-1.20)^{*} \\
-0.66(-2.90) * \\
\end{array}$ \\
\hline $\begin{array}{l}\text { Hooper }(1978, \text { table } 3) / \\
\text { Nonoil }\end{array}$ & $\begin{array}{l}\text { OLS/Exog. } \\
16\end{array}$ & $\begin{array}{l}\text { Static;Yes; } \\
\text { GNP }\end{array}$ & $\begin{array}{l}\text { Multilateral/ } \\
\text { Q;1955-77 } \\
\end{array}$ & U.S. & $2.03(10.65)$ & $-1.04(-3.90)$ \\
\hline $\begin{array}{l}\text { Lawrence (1978, table } \\
6 \text { )/Nonoil }\end{array}$ & $\begin{array}{l}\text { OLS/Exog. } \\
17\end{array}$ & $\begin{array}{l}\text { DL/; Yes; } \\
\text { WPI }\end{array}$ & $\begin{array}{l}\text { Multilateral/ } \\
\text { S;1962-77 } \\
\end{array}$ & U.S. & $3.08(27.00)$ & $-1.52(-4.70)$ \\
\hline $\begin{array}{l}\text { Stern, Baum, and Green } \\
(1979, \text { table } 2) / \text { Total }\end{array}$ & $\begin{array}{l}\text { OLS/Exog. } \\
18 \\
\end{array}$ & $\begin{array}{l}\text { DL; No; } \\
\text { WPI }\end{array}$ & $\begin{array}{l}\text { Multilateral/ } \\
Q ; 1953-76 \\
\end{array}$ & U.S. & $1.12(3.24)$ & $-2.18(-3.41)$ \\
\hline $\begin{array}{l}\text { Wilson and Takacs } \\
(1979, \text { tables } 1,4,6) / \\
\text { Nonoil }\end{array}$ & $\begin{array}{l}\text { OLS/Exog. } \\
19,41,59\end{array}$ & $\begin{array}{l}\text { Shiller; No; } \\
\text { WPI }\end{array}$ & $\begin{array}{l}\text { Multilateral/ } \\
\text { Q;1957-71 }\end{array}$ & $\begin{array}{l}\text { U.S. } \\
\text { Canada } \\
\text { Japan } \\
\end{array}$ & $\begin{array}{l}4.08(8.66) \\
1.87(4.91) \\
1.69(7.15) \\
\end{array}$ & $\begin{array}{l}-4.78(-1.00 \mathrm{i}) \\
-2.75(-1.00 \mathrm{i}) \\
-1.25(-1.00 \mathrm{i}) \\
\end{array}$ \\
\hline $\begin{array}{l}\text { Akhtar }(1980 \text {, table } 3) / \\
\text { Total }\end{array}$ & $\begin{array}{l}\text { OLS/Exog. } \\
49,50,60\end{array}$ & $\begin{array}{l}\text { RL; Yes; } \\
\text { WPI }\end{array}$ & $\begin{array}{l}\text { Multilateral/ } \\
\text { Q; 1970-76 }\end{array}$ & $\begin{array}{l}\text { U.S. } \\
\text { Canada } \\
\text { Japan } \\
\end{array}$ & $\begin{array}{l}2.47(2.00 \mathrm{i}) \\
1.49(2.00 \mathrm{i}) \\
1.54(2.00 \mathrm{i}) \\
\end{array}$ & $\begin{array}{l}-0.40(2.00 \mathrm{i}) \\
-0.76(2.00 \mathrm{i}) \\
-0.50(2.00 \mathrm{i}) \\
\end{array}$ \\
\hline $\begin{array}{l}\text { Goldstein, Khan, and } \\
\text { Officer }(1980, \text { table } 3) / \\
\text { Total }\end{array}$ & $\begin{array}{l}\text { OLS/Exog. } \\
20,42\end{array}$ & $\begin{array}{l}\text { Static; Yes; } \\
\text { Tradeable }\end{array}$ & $\begin{array}{l}\text { Multilateral/ } \\
\text { A;1950-73 }\end{array}$ & $\begin{array}{l}\text { U.S. } \\
\text { Canada }\end{array}$ & $\begin{array}{l}2.52(6.37) \\
1.45(8.05)\end{array}$ & $\begin{array}{l}-0.68(-3.33) \\
-0.82(-2.95)\end{array}$ \\
\hline $\begin{array}{l}\text { Geraci and Prewo } \\
(1982, \text { table 1)/ Total }\end{array}$ & $\begin{array}{l}\text { OLS/Exog. } \\
21,61\end{array}$ & $\begin{array}{l}\text { Koyck; Yes; } \\
\text { Tradeable } \\
\end{array}$ & $\begin{array}{l}\text { Bilateral/ } \\
Q ; 1958-74 \\
\end{array}$ & $\begin{array}{l}\text { U.S. } \\
\text { Japan }\end{array}$ & $\begin{array}{l}1.53(10.2) \\
0.77(9.76) \\
\end{array}$ & $\begin{array}{l}-1.23(-2.20) \\
-0.72(-1.50) \\
\end{array}$ \\
\hline $\begin{array}{l}\text { Haynes and Stone } \\
(1983, \text { table 1)/ Total }\end{array}$ & $\begin{array}{l}\text { OLS/Exog. } \\
22 \\
\end{array}$ & $\begin{array}{l}\text { Static/; No; } \\
\text { WPI }\end{array}$ & $\begin{array}{l}\text { Multilateral/ } \\
\text { Q;1955-79 }\end{array}$ & U.S. & $1.83(9.42)$ & $-0.51(-3.16)$ \\
\hline $\begin{array}{l}\text { Ueda (1983, table 1)/ } \\
\text { Total }\end{array}$ & $\begin{array}{l}\text { IV/Endog. } \\
62 \\
\end{array}$ & $\begin{array}{l}\text { Koyck; No; } \\
\text { Manufacture } \\
\end{array}$ & $\begin{array}{l}\text { Multilateral/ } \\
\text { S; 1966-80 } \\
\end{array}$ & Japan & $1.04(2.58)$ & $-1.40(-2.78)$ \\
\hline $\begin{array}{l}\text { Warner and Kreinin } \\
(1983 \text {, table } 2) / \text { Nonoil }\end{array}$ & $\begin{array}{l}\text { OLS/Exog. } \\
23,43,63\end{array}$ & $\begin{array}{l}\text { PDL; No; } \\
\text { WPI }\end{array}$ & $\begin{array}{l}\text { Multilateral/ } \\
\text { Q;1970-80 }\end{array}$ & $\begin{array}{l}\text { U.S. } \\
\text { Canada } \\
\text { Japan } \\
\end{array}$ & $\begin{array}{l}2.01(2.00 \mathrm{i}) \\
1.82(2.00 \mathrm{i}) \\
0.41(1.00 \mathrm{i}) \\
\end{array}$ & $\begin{array}{l}-2.53(-2.00 \mathrm{i}) \\
-1.00(-2.00 \mathrm{i}) \\
-0.72(-2.00 \mathrm{i}) \\
\end{array}$ \\
\hline $\begin{array}{l}\text { Helkie and Hooper } \\
(1988, \text { table } 4) / \text { Nonoil }\end{array}$ & $\begin{array}{l}\text { OLS/Exog. } \\
24\end{array}$ & $\begin{array}{l}\text { PDL; Yes; } \\
\text { GNP }\end{array}$ & $\begin{array}{l}\text { Multilateral/ } \\
\text { Q;1969-84 } \\
\end{array}$ & U.S. & $2.11(5.30)$ & $-1.115(-10.0)$ \\
\hline $\begin{array}{l}\text { Cline (1989, table } \\
\text { 4A.3)/ Total }\end{array}$ & $\begin{array}{l}\text { OLS/Exog. } \\
31,44,64\end{array}$ & $\begin{array}{l}\text { DL; Yes; } \\
\text { WPI }\end{array}$ & $\begin{array}{l}\text { Multilateral/ } \\
\text { Q;1973-87 }\end{array}$ & $\begin{array}{l}\text { U.S. } \\
\text { Canada } \\
\text { Japan } \\
\end{array}$ & $\begin{array}{l}2.44(2.00 \mathrm{i}) \\
2.01(2.00 \mathrm{i}) \\
1.21(2.00 \mathrm{i}) \\
\end{array}$ & $\begin{array}{l}-1.36(-1.00 \mathrm{i}) \\
-2.35(-1.00 \mathrm{i}) \\
-0.69(-1.00 \mathrm{i}) \\
\end{array}$ \\
\hline $\begin{array}{l}\text { Deyak, Sawyer, and } \\
\text { Sprinkle (1989, table } \\
\text { 1)/ Total }\end{array}$ & $\begin{array}{l}\text { OLS/Exog. } \\
25\end{array}$ & $\begin{array}{l}\text { Koyck; Yes; } \\
\text { WPI }\end{array}$ & $\begin{array}{l}\text { Multilateral/ } \\
\text { Q;1958-83 }\end{array}$ & U.S. & $1.07(4.60)$ & $-0.2 .9(-1.00)$ \\
\hline
\end{tabular}


Table Al (continued)

Chronology of Elasticity Estimates: Selected Studies for Canada, Japan, and the United States

\begin{tabular}{|c|c|c|c|c|c|c|}
\hline \multirow[t]{2}{*}{ Study/ Trade Data } & \multirow{2}{*}{$\begin{array}{l}\text { Estimator/ } \\
\text { Price } \\
\text { Behavior/\# }\end{array}$} & \multirow{2}{*}{$\begin{array}{l}\text { Dyn. Struc; } \\
\text { Homogeneity; } \\
\text { Domestic Pr. }\end{array}$} & \multirow{2}{*}{$\begin{array}{l}\text { Price Data/ } \\
\text { Frequency; } \\
\text { Sample } \\
\end{array}$} & \multirow[t]{2}{*}{ Country } & \multicolumn{2}{|c|}{ Elasticity Estimates } \\
\hline & & & & & Income (t-stat) & Price (t-stat) \\
\hline $\begin{array}{l}\text { Dunvley and Deyak } \\
(1989, \text { table: } 2) / \text { Total }\end{array}$ & $\begin{array}{l}\text { OLS/Exog. } \\
51,52\end{array}$ & $\begin{array}{l}\text { Static; No; } \\
\text { WPI }\end{array}$ & $\begin{array}{l}\text { Multilateral/ } \\
\text { Q;1957-65 } \\
\text { Q;1973-82 }\end{array}$ & Canada & $\begin{array}{l}1.08(2.85) \\
0.54(1.42)\end{array}$ & $\begin{array}{l}-1.50(-2.53) \\
-0.20(-0.92)\end{array}$ \\
\hline $\begin{array}{l}\text { Krugman (1989a, table } \\
\text { 3)/Nonoil }\end{array}$ & $\begin{array}{l}\text { OLS/Exog. } \\
26,45,65\end{array}$ & $\begin{array}{l}\text { DL; Yes; } \\
\text { Manufacture }\end{array}$ & $\begin{array}{l}\text { Multilateral/ } \\
\text { A;1971-86 }\end{array}$ & $\begin{array}{l}\text { U.S. } \\
\text { Canada } \\
\text { Japan } \\
\end{array}$ & $\begin{array}{l}1.31(2.98) \\
1.66(6.15) \\
0.80(0.67) \\
\end{array}$ & $\begin{array}{l}-0.93(-3.10) \\
-1.45(-2.90) \\
-0.42(-1.32) \\
\end{array}$ \\
\hline $\begin{array}{l}\text { Moffet }(1989, \text { table } 5) / \\
\text { Total }\end{array}$ & $\begin{array}{l}\text { OLS/Exog. } \\
27 \\
\end{array}$ & $\begin{array}{l}\text { PDL; No; } \\
\text { CPI }\end{array}$ & $\begin{array}{l}\text { Multilateral/ } \\
\text { Q;1967-87 } \\
\end{array}$ & U.S. & $2.50(9.07)$ & $-0.69(-7.40)$ \\
\hline $\begin{array}{l}\text { Noland }(1989, \text { table } 1) / \\
\text { Total }\end{array}$ & $\begin{array}{l}\text { Grid./OLS/ } \\
\text { Exog.66 } \\
\end{array}$ & $\begin{array}{l}\text { GDL; Yes; } \\
\text { Overall } \\
\end{array}$ & $\begin{array}{l}\text { Multilateral/ } \\
\text { Q; } 1970-85\end{array}$ & Japan & $1.66(2.00 \mathrm{i})$ & $-0.67(-3.00 \mathrm{i})$ \\
\hline $\begin{array}{l}\text { Lawrence (1990, table } \\
\text { 8)/Nonoil }\end{array}$ & $\begin{array}{l}\text { OLS/Exog. } \\
28 \\
\end{array}$ & $\begin{array}{l}\text { PDL; Yes } \\
\text { WPI }\end{array}$ & $\begin{array}{l}\text { Multilateral/ } \\
\mathrm{S} ; 1976-90 \\
\end{array}$ & U.S. & $0.73(3.00)$ & $-1.47(-14.3)$ \\
\hline $\begin{array}{l}\text { Marquez (1990, table } \\
\text { 2)/ Total }\end{array}$ & $\begin{array}{l}\text { OLS/Exog. } \\
29,46,67\end{array}$ & $\begin{array}{l}\text { RL; Yes; } \\
\text { GNP }\end{array}$ & $\begin{array}{l}\text { Multilateral/ } \\
\text { Q;1973-85 }\end{array}$ & $\begin{array}{l}\text { U.S. } \\
\text { Canada } \\
\text { Japan } \\
\end{array}$ & $\begin{array}{l}1.94(4.97) \\
1.84(8.00) \\
0.35(1.67) \\
\end{array}$ & $\begin{array}{l}-0.92(-4.80) \\
-1.02(-4.43) \\
-0.93(-4.43) \\
\end{array}$ \\
\hline $\begin{array}{l}\text { Blecker (1992, table A- } \\
\text { 1)/Nonoil }\end{array}$ & $\begin{array}{l}\text { OLS/Exog. } \\
32 \\
\end{array}$ & $\begin{array}{l}\text { PDL; Yes; } \\
\text { CPI }\end{array}$ & $\begin{array}{l}\text { Multilateral/ } \\
\text { Q;1975-89 } \\
\end{array}$ & U.S. & $2.56(3.00)$ & $-0.97(-2.00)$ \\
\hline $\begin{array}{l}\text { Deyak, Savryer, and } \\
\text { Sprinkle (1993, table } \\
\text { 2)/ Total }\end{array}$ & $\begin{array}{l}\text { OLS/Exog. } \\
68\end{array}$ & $\begin{array}{l}\text { PDL;No; } \\
\text { WPI }\end{array}$ & $\begin{array}{l}\text { Multilateral/ } \\
\text { Q;1958-89 }\end{array}$ & Canada & $1.66(22.25)$ & $-0.82(-2.75)$ \\
\hline $\begin{array}{l}\text { Zietz and Pemberton } \\
(1993, \text { table 5)/ Nonoil }\end{array}$ & $\begin{array}{l}\text { OLS/Exog. } \\
33 \\
\end{array}$ & $\begin{array}{l}\text { DL; Yes; } \\
\text { WPI }\end{array}$ & $\begin{array}{l}\text { Multilateral/ } \\
\text { Q;1976-90 } \\
\end{array}$ & U.S. & $2.48(40.9)$ & $-1.14(-15.5)$ \\
\hline $\begin{array}{l}\text { Clarida }(1 s 94, \text { p.306)/ } \\
\text { Nonoil }\end{array}$ & $\begin{array}{l}\text { NLS/Exog. } \\
30\end{array}$ & $\begin{array}{l}\text { ECM-DL; } \\
\text { Yes; } \\
\text { Non-durable } \\
\text { Consumption }\end{array}$ & $\begin{array}{l}\text { Multilateral/ } \\
\text { Q;1968-90 }\end{array}$ & U.S. & $2.15(1.00 \mathrm{i})$ & $-0.95(-1.00 \mathrm{i})$ \\
\hline
\end{tabular}




\section{Appendix B: Data Sources}

The data for imports recognizes the differential role of oil in imports of these three countries. This consideration is important because foreign and domestic oil are perfect substitutes and these three countries differ in the extent to which domestic oil production meets their domestic requirements. Canadian oil requirements are met by domestic oil production but Canadian data on imports include a relatively small amount of oil imports (five percent, OECD 1990) because of an arrangement to trade oil with the United States that avoids cross-continental shipments of oil in these two countries; thus I focus on total Canadian imports. Japanese oil requirements are entirely met from foreign sources meaning that the distinction between domestic and foreign oil is irrelevant; thus I focus on explaining total imports. One could argue in favor of excluding oil from the measure of imports to avoid the volatility of prices. This argument applies with equal force to much of Japanese imports: Based on OECD (1990, p. 148), oil imports represent 27 percent of Japanese imports in 1989 compared to 31 percent for other non-manufactured products. Excluding oil imports from the analysis ignores that other commodities exhibit just as much price fluctuation as oil and that, as mentioned earlier, price fluctuations of the postwar pale in comparison to those of the earlier period. Finally, U.S. oil production meets half of U.S. oil requirements and thus excluding oil imports from the measure of imports is important because otherwise the data would contradict the assumptions of the imperfect substitute model.

Figure B1 shows annual data for the logarithms of the GNP deflator and the tariff-adjusted import price along with the tariff rate since 1890 for each country. The data reveal substantial price instability from 1890 to 1940 including the deflationary pressures of the 1930s. Since 1973, increases in the GNP deflator have been interrupted by the recessions of 1980 and 1990. Up to 1945, import prices show fluctuations as large as those of the GNP deflator especially during the WWI period. The decline in import prices in 1920 is the largest decline over the last century. Finally, I measure tariff rates as the ratio between the level of duties and nominal merchandise imports excluding tariffs. U.S. and Canadian tariff rates show a sustained decline since 1890 with the exception of the 1930s; Japanese tariff rates exhibit a relatively high volatility, an observation already made by Minami (1994). Indeed the series shown in figure 2 coincide very closely to Minami's series even though the two series are derived independently.

\section{Canada}

1. Real GDP in 1986 Prices:

1961-1993: Canadian Economic Observer, Ottawa: Statistics Canada, various issues.

1926-1960: Backward extrapolation. Liesner (1989, pp. 154-55).

1890-1925: Backward extrapolation. Urquhart (1993, p. 25). 
FIGURE B1: Prices and Tariffs: 1890-1992

Canadian Import (solid) and Expendiarre (dashed) Prices, logs
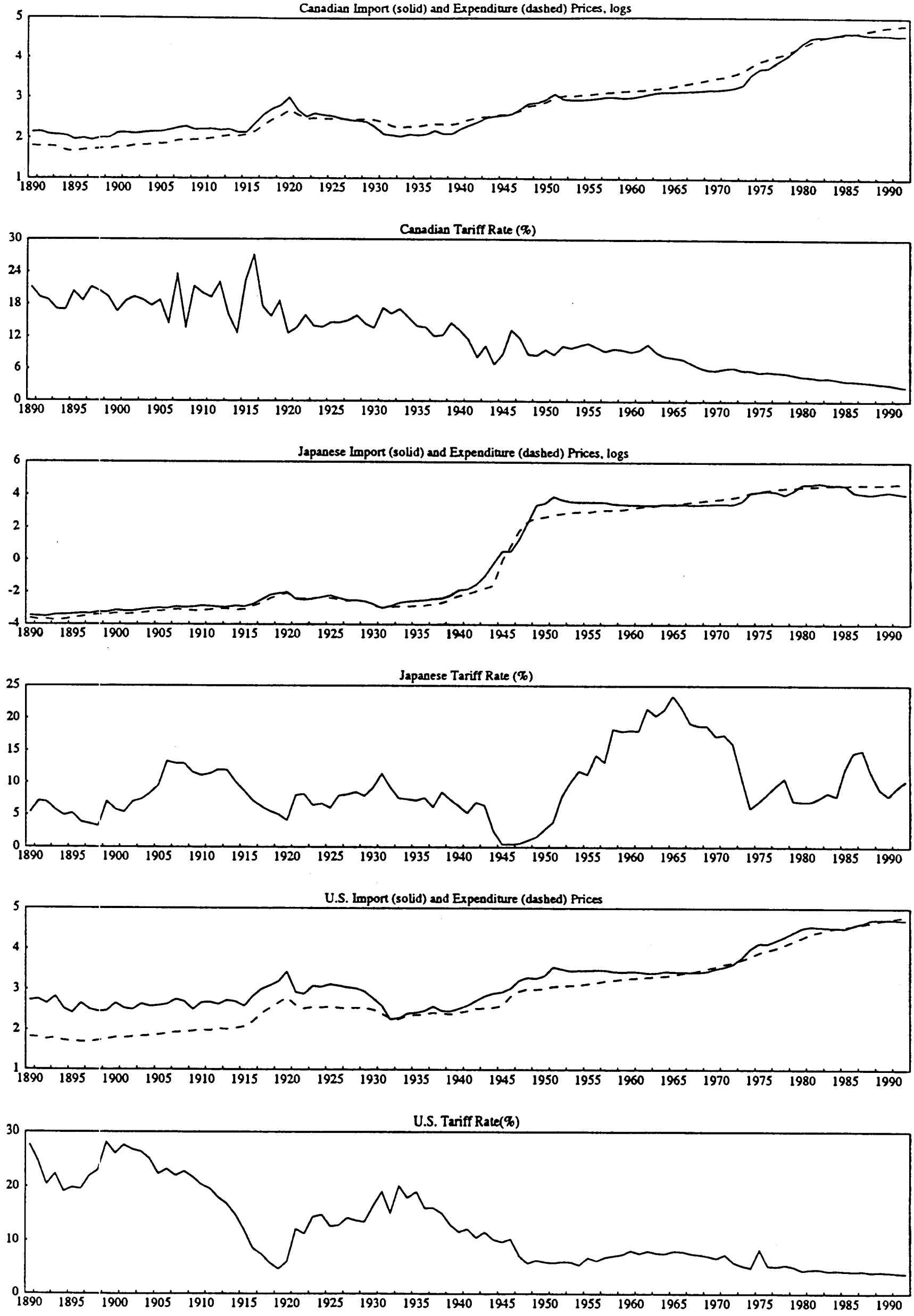
2. Nominal GDP:

1961-1993: Canadian Economic Observer, Ottawa: Statistics Canada, various issues.

1926-1960: Backward extrapolation. Liesner (1989, pp. 152-53).

1890-1925: Backward extrapolation. Urquhart (1993, p. 25).

3. Merchandise Nominal Imports:

1946-1993: Summary of Canadian International Trade, Catalogue 65-001, Ottawa: Statistics

Canada, various issues.

1890-1945: Backward extrapolation. Liesner (1989, pp. 172-173).

4. Merchandise Nominal Exports:

1946-1993: Summary of Canadian International Trade, Catalogue 65-001, Ottawa: Statistics

Canada, various issues.

1890-1945: Backward extrapolation. Liesner (1989, pp. 172-173).

5. Price of Imports:

Index of Import Unit Value.

1986-1993: Summary of Canadian International Trade, Catalogue 65-001, Ottawa: Statistics Canada, various issues.

1975-1985: Backward extrapolation. International Financial Statistics Yearbook, Washington, DC: International Monetary Fund, 1992.

1890-1974: Backward extrapolation. Liesner (1989, pp. 160-161).

6. Price of Exports:

Index of Export Unit Value.

1986-1993: Summary of Canadian International Trade, Catalogue 65-001, Ottawa: Statistics Canada, various issues.

1975-1985: Backward extrapolation. International Financial Statistics Yearbook, Washington, DC: International Monetary Fund, 1992.

1890-1974: Backward extrapolation. Liesner (1989, pp. 160-161).

7. Population:

1946-1993: International Financial Statistics Yearbook, Washington DC: International Monetary Fund, 1992.

1890-1945: Backward extrapolation. Liesner (1989, pp. 162-163).

8. Customs Duties:

1989-1992: Canada Year Book, 1994, table 9-5, Ottawa: Statistics Canada, 1993.

1978-1988: Backward extrapolation. National Income and Expenditure Accounts 1978..1989, table 52, Ottawa: Minister of Supply and Services, 1990.

1969-1977: Backward extrapolation. National Income and Expenditure Accounts 1969.-1983, table 46, Ottawa: Minister of Supply and Services, 1984.

1890-1968: Backward extrapolation. Historical Statistics of Canada, series H1-H18, Ottawa:

Canadian Government Publishing Centre, 1993.

9. TariffRate:

Ratio of custom duties (\#8) to nominal imports (\#3).

10. Real Imports in 1986 prices: 
Nominal imports (\#3) deflated by the price of imports (\#5).

11. Real Exports in 1986 prices:

Nominal exports (\#4) deflated by the price of exports (\#6).

12. Real Domestic Expenditures in 1986 prices:

Real GDP (\#1) + real imports (\#10) - real exports (\#11).

13. GDP Defiator:

Nominal GDP (\#2) divided by real GDP (\#1).

14. Relative Price of Imports:

Ratic of the product of the import price (\#5) times one plus the tariff rate (\#9) to the GDP deflator (\#13).

15. Government Expenditures:

1961-1993: Canadian Economic Observer, Ottawa: Statistics Canada, various issues.

1926-1960: Backward extrapolation. Liesner (1989, pp. 154-155).

1890-1925: Backward extrapolation. Urquhart (1993, pp. 27-28).

Japan

1. Real GNP in 1986 Prices:

1961-1993: Economic Statistics Monthly, table 127(3), Tokyo: Bank of Japan, various issues.

1930 1960: Backward extrapolation. Liesner (1989, pp. 252-253).

1890-1929: Backward extrapolation. Ohkawa (1957, p. 248).

2. Nominal GNP:

1961-1993: Economic Statistics Monthly, table 127(4), Tokyo: Bank of Japan, various issues.

1930-1960: Backward extrapolation. Liesner (1989, pp. 252).

1890-1929: Backward extrapolation. Ohkawa (1957, p. 247).

3. GNP Deflator:

Ratio of nominal GNP (\#2) and real GNP (\#1).

4. Population:

1961-1993: International Finance Statistics, Washington, DC: International Monetary Fund.

1890.1960: Backward extrapolation. Hundred Year Statistics of the Japanese Economy, Tokyo:

The Bank of Japan, 1966, pp. 12-13.

\section{Nominal Ex:ports:}

1961-1993: Japan Economic Indicators, Tokyo: Economic Planning Agency, various issues.

1890-1960: Backward extrapolation. Liesner (1989, pp. 268-269).

\section{Nominal Imports:}

1961-1993: International Finance Statistics, Washington, DC: International Monetary Fund.

1890-1960: Backward extrapolation. Hundred Year Statistics of the Japanese Economy, pp. 278279, Tokyo: The Bank of Japan, 1966. 
7. Customs and Tariffs:

1992-1993: Financial Statistics of Japan, tables 3-8, Tokyo: Institute of Fiscal and Monetary Policy, 1993. Sum of Customs Duties, Gasoline Taxes, and Tobacco Taxes.

1989-1991: Japan Statistical Yearbook, 1991, p. 452, Tokyo: Statistics Bureau, Management and Coordination Agency, 1991. Sum of Customs Duties, Gasoline Taxes, Sugar Excise, and Tobacco Taxes.

1985-1988: Japan Statistical Yearbook, 1989, p. 450, Tokyo: Statistics Bureau, Management and Coordination Agency, 1989. Sum of Customs Duties, Gasoline Taxes, Sugar Excise, and Tobacco Taxes.

1890-1984: Liesner (1989, pp. 268-269).

\section{Import Prices:}

1961-1992: Economic Statistics Monthly, table 91 (3), Tokyo: Bank of Japan, various issues.

1953-1960: Backward extrapolation. Ohkawa and Shinohara (1979, p. 331).

1940-1952: Backward extrapolation using growth rates of the author's aggregate commodity price index for Japan's imports. The commodities are coal, cotton, hides, iron, oil, phosphate, rice, rubber, sugar, wheat, wool. For each of these commodities I use the ratio between the value of these imports and the associated quantities; the data are in Hundred Year Statistics of the Japanese Economy, Tokyo: The Bank of Japan, 1966, pp. 286-289. For oil, the source does not report the price of oil during the war years. Thus I convert the U.S. oil import price (see below) from U.S.

dollars to yen. To get the yen/dollar rate during the war years, I use the rate implied by the yen/pound and dollar/pound rates as available in Liesner (1989).

1890-1939: Backward extrapolation. Ohkawa and Shinohara (1979, p. 331).

9. Real Imports in 1985 Prices:

Ratio of nominal imports (\#6) to the import price (\#8).

10. Tariff Rate:

Ratio of the value of custom duties (\#7) to the value of imports (\#6).

11. Real Exports in 1985 prices:

Nominal exports (\#5) deflated by the GNP deflator (\#3).

12. Real Domestic Expenditures in 1986 prices:

Real GNP (\#1) + real imports (\#9) - real exports (\#11).

13. Relative Price of Imports:

Ratio of the product of the import price (\#8) times one plus the tariff rate (\#10) to the GNP deflator (\#3).

\section{Real Government Expenditures:}

1961-1993: Economic Statistics Monthly, table 127(3), Tokyo: Bank of Japan, various issues.

1930-1960: Backward extrapolation. Liesner (1989, p. 253).

1890-1929: Backward extrapolation. Hundred Year Statistics of the Japanese Economy, Tokyo:

The Bank of Japan, 1966, p. 33.

\section{Currency in Circulation:}

1961-1992: Bank of Japan, various issues. 
18901-1928: Backward extrapolation. Hundred Year Statistics of the Japanese Economy, Tokyo: The Bank of Japan, 1966, p. 166.

\section{United States.}

The main data sources are the Survey of Current Business and the Historical Statistics of the United States: Colonial Time to 1970 assembled by the Bureau of Economic Analysis of the U.S. Department of Commerce; alternative sources are explicitly indicated whenever they are used. The Bureau of Economic Analysis offers data over 192:9-92 with "real" variables expressed in 1987 prices. For the period 1890-1928, the Historical Statistics offers a comparable database but uses a different base year to deflate nominal magnitudes. Thus to obtain data for the 1890-1928 period in 1987 prices, I extrapolate backwards the series from the Survey using the growth rates of the series of the Historical Statistics.

\section{Real GNP in 1987 Prices:}

19291-1992: Survey of Current Business, December 1992, table 2.

189(1-1928: Backward extrapolation using growth rates from Historical Statistics of the United

States:Colonial Time to 1970, p. 224, series F-3.

I use GNP as a measure of income instead of GDP because data for GDP are not readily available for the 19th century and the early part of the 20th century.

\section{Total Resident Population:}

1929-1992: Survey of Current Business, table 2.1.

18901-1928: Backward extrapolation using growth rates from Historical Statistics of the United

States:Colonial Time to 1970, p. 8, series A-7.

The data on population include Armed Forces overseas. Data for population including Armed Forces prior to 1930 are not available except for 1917-19 which appear in footnote 1 of page 8 of Historical Statistics. I adjust the growth rate to include Armed Forces overseas for 1917-19.

\section{Merchandise Imports in Current Prices:}

192S-1992: Survey of Current Business, table 4.1.

18901-1928: Backward extrapolation using growth rates from Historical Statistics of the United States: Colonial Time to 1970, p. 889, series U-219.

\section{Merchandise Imports in 1987 Prices:}

1929-1992: Survey of Current Business, table 4.2.

18901-1928: Backward extrapolation using growth rates from Historical Statistics of the United States:Colonial Time to 1970, p. 893, series U-237.

\section{Imports of Petroleum and Petroleum Products in Current Prices:}

1965-1992: Survey of Current Business, table 3.B, U.S. Merchandise Trade.

1908-1964: Backward extrapolation using growth rates from Historical Statistics of the United States:Colonial Time to 1970, p. 900, series U-316.

189C-1907: Volume of oil imports are negligible (Historical Statistics of the United States: Colonial Time to 1970, series M-140) and set to zero.

6. Imports of Petroleum and Petroleum Products in 1987 Prices:

Impcrts of petroleum and products in current prices (\#5) deflated by the associated price index (\#10 
below).

7. Non-oil Imports in Current Prices:

Difference between total imports in current prices (\#3) and oil imports in current prices; (\#5).

8. Non-oil Imports in 1987 Prices:

Difference between total imports in 1987 prices (\#4) and oil imports in 1987 prices (\#1).

9. GNP Deflator:

1929-1992: Ratio between nominal and real GNP; for data on nominal GNP: Survey of Current Business, December 1992, table 1.

1890-1928: Backward extrapolation using growth rates from Historical Statistics of tize United States:Colonial Time to 1970, p. 224, series F-5.

10. Oil-import Price Deflator:

1967-1992: Ratio between current-price and 1987-price data for fuel imports (BOP basis) from the

U.S. Commerce Department, Merchandise Trade Statistical Release.

1947-1966: Grows at the rate of the U.S. domestic price of oil (Producer Price Index Press Release, Bureau of Labor Statistics).

1890-1946: Grows at the rate of the price of domestic petroleum production (\$/barrel): Historical

Statistics of the United States: Colonial Time to 1970, p. 593, series M-139.

11. Non-oil Import Price Deflator:

Ratio of non-oil imports in current prices (\#7) to non-oil imports in 1987 prices (\#8).

12. Custom Duties:

1929-1992: Survey of Current Business, table 3.2.

1890-1928: Backward extrapolation using growth rates from Historical Statistics of tine United States:Colonial Time to 1970, p. 1105, series Y-344.

13. Export of Goods and Services in Current Prices:

1929-1992: Survey of Current Business, December 1992, table 1.

1890-1928: Backward extrapolation using growth rates from Historical Statistics of the United

States:Colonial Time to 1970, p. 891, series U-225 (index of export volume) times U-226 (index of export price).

14. Export of Goods and Services in 1987 Prices:

1929-1992: Survey of Current Business, December 1992, table 2.

1890-1928: Backward extrapolation using growth rates from Historical Statistics of the United

States:Colonial Time to 1970, p. 891, series U-225 (index of export volume).

15. Import of Goods and Services in Current Prices:

1929-1992: Survey of Current Business, December 1992, table 1.

1890-1928: Backward extrapolation using growth rates from Historical Statistics of the United

States:Colonial Time to 1970, p. 890, series U-219.

16. Import of Goods and Services in 1987 Prices:

1929-1992: Survey of Current Business, December 1992, table 2.

1890-1928: Backward extrapolation using growth rates from Historical Statistics of the United 
States:Colonial Time to 1970, p. 893, series U-237.

17. Domestic: Expenditures in Current Prices:

GNP' in 1987 prices (\#1) times GNP deflator (\#9) + imports of goods and services in current prices (\#15) - exports of goods and services in current prices (\#13).

18. Domestic Expenditures in 1987 Prices:

GNP' in 1987 prices (\#1) + imports of goods and services in 1987 prices (\#16) - exports of goods and services in 1987 prices (\#14).

19. Price Deflator for Domestic Expenditures:

Ratio between domestic expenditures in current prices (\#17) and 1987 prices (\#18).

20. Government Purchases in Current Prices:

1929-1992: Survey of Current Business, table 1.1.

18910-1928: Backward extrapolation using growth rates from Liesner (1989), table US.1, p. 74.

Real government purchases equal nominal government purchases (\#20) deflated by the GNP deflator (\#9). 
References

Ahluwalia, Isher and Ernesto Hernández-Catá, "An Econometric Model of U.S. Merchandise Imports Under Fixed and Fluctuating Exchange Rates, 1959-73," IMF Staff Papers, 22, 1975, 791-824.

Akhtar, M., "Income and Price Elasticities of Imports in Industrial Countries," Business Economics, 15, 1980, 69-75.

Alterman, William, "Using Disaggregated Data to Dissect the U.S. Trade Deficit," mimeo, U.S. Department of Labor, 1993.

Baba, Masao and Masahiro Tatemoto, "Foreign Trade and Economic Growth in Japan: 1858-1937," in Klein, Lawrence and Kazushi, Ohkawa (eds.), Economic Growth: The Japanese Experience since the Meiji Era, Homewood: Richard Irwin, 1968.

Banerjee Anindya, Juan Dolado, John Galbraith, and David F. Hendry, Co-integration, Error-correction, and the Econometric Analysis of Non-Stationary Data, Oxford: Oxford University Press, 1993.

Barnett, William, "Theoretical Foundations of the Rotterdam Model," Review of Economic Studies, 46, 1579, 109-130.

Barnett, William, "On the Flexibility of the Rotterdam Model: A First Empirical Look," European Economic Review, 6, $1984,285-289$.

Barten, Anton, "Consumer Demand Functions Under Conditions of Almost Additive Preferences," Econometrica, 32 , 1964, 1-38.

Blecker, Robert, Beyond the Twin Deficits, New York: M.E. Sharpe, 1992.

Branson, William, "Trends in United States International Trade and Investment since World War," in Martin Feldstein (ed.) The American Economy in Transition, Chicago: University of Chicago Press, 1980.

Byron, R., "On the Flexibility of the Rotterdam Model," European Economic Review, 6, 1984, 273-283.

Caves, Richard and Richard Holton, The Canadian Economy: Prospect and Retrospect, Cambridge: Harrard University Press, 1959.

Chang, Tse Chun, "International Comparison of Demand for Imports," Review of Economic Studies, 13, 1946, 53-67.

Clarida, Richard, "Co-integration, Aggregate Consumption, and the Demand for Imports: A Structural Eccnometric Investigation," American Economic Review, 84, 1994, 208-308.

Clark, Peter B., "The Effects of Recent Exchange Rate Changes on the U.S. Trade Balance," in Peter Clark, Dennis Logue and Richard Sweeney (eds.) The Effects of Exchange Rate Adjustments, Washington, D.C.: U.S. Treasury, 1974.

Cline, William, United States External Adjustment and the World Economy, Washington D.C.: Institute for International Economics, 1989.

Cohen, Jerome, Japan's Economy in War and Reconstruction, Minneapolis: University of Minnesota Press, 1949.

Cohen, Jerome, Japan's Postwar Economy, Bloomington: Indiana University Press, 1958.

Deaton, Angus and John Muellbauer, "An Almost Ideal Demand System," American Economic Review, 7C, 1980a, 312 326. 
Deaton, Angus and John Muellbauer, Economics and Consumer Behavior, Cambridge: Cambridge University Press, $198 \mathrm{Clb}$.

Deppler, Michael and Duncan Ripley, "The World Trade Model: Merchandise Trade," IMF Staff Papers, 25, 1978, 147-206.

Deyak, Timothy, W. Charles Sawyer, and Richard Sprinkle, "An Empirical Examination of the Structural Stability of Disaggregated U.S. Import Demand," Review of Economics and Statistics, 71, 1989, 337-341.

Deyak, Timothy, W. Charles Sawyer, and Richard Sprinkle, "The Adjustment of Canadian Import Demand to Changes in Income, Prices, and Exchange Rates, " Canadian Journal of Economics, 26, 1993, 890-900.

Dickey, Davicl and Sastry Pantula, "Determining the Order of Differencing in Autoregressive Process," Journal of Business and Economic Statistics, 5, 1987, 455-461.

Doornik, Jurgen and David F. Hendry, PC-GIVE: Version 8, Oxford: Institute of Economic and Statistics, University of Oxford, 1994.

Dornbusch, Rudiger and Stanley Fischer, "The Open Economy: Implications for Monetary and Fiscal Policy," in Robert Gordon (ed.) The American Business Cycle: Continuity and Change, Chicago: University of Chicago Press, 1986 .

Dunvely, James and Timothy Deyak, "Seasonal, Cyclical, and Secular Stability of Canadian Aggregate Demand for Merchandise Imports, 1957-1982," Applied Economics, 21, 1989, 449-459.

Engle, Robert, "Autoregressive Conditional Heteroscedasticity, with Estimates of the Variance of United Kingdom Inflations," Econometrica, 50, 1982, 987-1008.

Engle, Roberl., David Hendry and J.F. Richard, "Exogeneity," Econometrica, 51, 1983, 277-304.

Geraci, Vincent and Wilfred Prewo, "An Empirical Demand and Supply Model of Multilateral Trade," Review of Economics and Statistics, 64, 1982, 432-441.

Goldstein, Morris and Mohsin Khan, "Income and Price Effects in Foreign Trade," in Ronald Jones and Peter Kenen (eds.) Handbook of International Economics, vol. 2, Amsterdam: North-Holland, 1985.

Goldstein, Morris, Mohsin Khan, and Lawrence Officer, "Prices of Tradeable and Nontradeable Goods in the Demand for "Total Imports," Review of Economics and Statistics, 62, 1980, 190-199.

Green, Richard and Julian Alston,"Elasticities in AIDS Models," American Journal of Agricultural Economics, 72, 1990, 442-445.

Haynes, Stephen and Joe Stone, "Secular and Cyclical Responses of U.S. Trade to Income: An Evaluation of Traditional Models," Review of Economics and Statistics, 65, 1983, 87-95.

Heien, Dale, "Structural Stability and the Estimation of International Import Price Elasticities," Kyklos, 21, 1968, 695-711.

Helkie, William and Peter Hooper, "The U.S. External Deficit in the 1980s: An Empirical Analysis," in Ralph Bryant, Gerald Holtham and Peter Hooper (eds.) External Deficits and the Dollar: The Pit and the Pendulum, Washington, D.C.: Brookings Institution, 1988.

Hooper, Peter, "Forecasting U.S. Export and Import Prices and Volumes in a Changing World Economy," Federal Reserve Board, International Finance Discussion Paper No. 99, 1976. 
Hooper, Peter, "The Stability of Income and Price Elasticities in U.S. Trade, 1975- 1977," Federal Reserve Board, International Finance Discussion Paper No. 119, 1978.

Houthakker, Hendrik and Stephen Magee, "Income and Price Elasticities in World Trade," Review of Economics and Statistics, 51, 1969, 111-125.

Johansen, Soren, "Statistical Analysis of Cointegration Vectors," Journal of Economic Dynamics and Control, 12, $1988,231-254$.

Johansen, Soren and Katherina Juselius, "Maximum Likelihood Estimation and Inference on Cointegration with Applications to the Demand for Money," Oxford Bulletin of Economics and Statistics, 52, 1989, 169-210.

Khan, Mohsin and Knud Ross, "Cyclical and Secular Income Elasticities of the Demand for Imports," Review of Economics and Statistics, 57, 1975, 357-361.

Khan, Mohsin and Knud Ross, "The Functional Form of the Aggregate Import Demand Equation," Journal of International Economics, 7, 1977, 149-160.

Klein, Lawrence and Kazushi Ohkawa (eds.), Economic Growth: The Japanese Experience since the Meiji Era, Homewood: Richard Irwin, 1968.

Kohli, Ulrich, Technology, Duality, and Foreign Trade, Ann Arbor: University of Michigan Press, 1991

Krause, Lawrence, "United States Imports, 1947-1958," Econometrica, 30, 1962, 221-238.

Kreinin, Mordechai, "Price Elasticities in International Trade," Review of Economics and Statistics, 49, 1967, 510-516.

Krugman, Paul, "Differences in Income Elasticities and Trends in Real Exchange Rates," European Economic Review, 33, 1989a, 1031-1054.

Krugman, Paul, Exchange Rate Instability, Cambridge: MIT Press, $1989 \mathrm{~b}$.

Kuznets, Simon, Modern Economic Growth: Rate, Structure, and Speed, New Haven: Yale University Press, 1966.

Lawrence, Robert, "An Analysis of the 1977 U.S. Trade Deficit," Brookings Papers on Economic Activity, No.1, 1978, 159-190.

Lawrence, Robert, "U.S. Current Account Adjustment: An Appraisal," Brookings Papers on Economic Activity, No. 2, 1990, 343-392.

Liesner, Thelma, One Hundred Years of Economic Statistics, New York: Facts on File Inc.,1989.

Lipsey, Robert, "U.S. Foreign Trade and The Balance of Payments, 1800-1913," National Bureau of Econiomic Research, Working Paper No. 4710, 1994.

Magee, Stephen, "Tariffs and U.S. Trade," Working paper No. 14, Graduate School of Business, Chicago: University of Chicago, 1972.

Marquez, Jaime, "Bilateral Trade Elasticities," Review of Economics and Statistics, 72, 1990, 70-77.

Marquez, Jaime, "The Autonomy of Trade Elasticities: Choice and Consequences," Federal Reserve Board, International Finance Discussion Paper No. 422, 1992.

Marr, William and Donald Paterson, Canada: An Economic History, Toronto: Macmillan, 1980. 
Marshall, Alfred, Principles of Economics, volume I: Text, London: Macmillan, 1961, ninth edition.

Miller, Joseph and Michele Fratianni, "The Lagged Adjustment of U.S. Trade to Prices and Income," Journal of Economics and Business, 26, 1974, 191-198.

Minami, Ryoshin, The Economic Development of Japan: A Quantitative Study, New York: St. Martin's Press, 1994.

Moffet, Michaıl, "The J-curve Revisited: An Empirical Examination for the United States," Journal of International Money and Finance, 8, 1989, 425- 444.

Murray, Tracy and Peter Ginman, "An Empirical Examination of the Traditional Aggregate Import Demand Model," Review of Economics and Statistics, 58, 1976, 75-80.

Noland, Marcus, "Japanese Trade Elasticities and the J-curve," Review of Economics and Statistics, 71, 1989, 175-1.79.

Officer, Lawrence, An Econometric Model of Canada under the Fluctuating Exchange Regime, Cambridge: Harvard University Press, 1968.

Ohkawa, Kazushi, The Growth Rate of the Japanese Economy since 1878, Tokyo: Institute of Economic Research, Hitotsubashi University, 1957.

Ohkawa, Kazushi and Henry Rosovsky, Japanese Economic Growth, Stanford: Stanford University Press, 1973.

Ohkawa, Kazushi and Miyohei Shinohara, Patterns of Japanese Economic Development: A Quantitative Appraisal, New .Haven: Yale University Press, 1979.

Organization for Economic Cooperation and Development, 1990, OECD Economic Outlook. June No.47, Paris.

Reinhardt, Car.men, "Devaluation, Relative Prices, and International Trade: Evidence from Developing Countries," Staff Papers, 42, 1995, 290-312.

Romer, Christina, "The Prewar Business Cycle Reconsidered: New Estimates of Gross National Product, 1869-1908," Journal of Political Economy, 97, 1989, 1-37.

Stern, Robert, Christopher Baum, and Mark Green, "Evidence on Structural Change in the Demand for Aggregate U.S. Imports and Exports," Journal of Political Economy, 87, 1979, 179-192.

Stern, Robert, Ionathan Francis, and Bruce Schumacher, Price Elasticities in International Trade: An Annotated Biblicigraphy, London: Macmillan, 1976.

Taplin, G., "A Model of World Trade," in R. Ball (ed.) The International Linkage of National Economic Models, Amsterdam: North-Holland, 1973.

Theil, Henri, "The Information Approach to Demand Analysis," Econometrica, 33, 1965, 67-87.

Thursby, Jerry and Marie Thursby, "How Reliable Are Simple, Single Equation Specifications of U.S. Import Demand?" Review of Economics and Statistics, 66, 1984, 120-128.

Ueda, Kazuo, "Trade Balance Adjustment with Imported Intermediate Goods: The Japanese Case," Review of Economics and Statistics, 65, 1983, 618-625.

Urquhart, Malcolm Charles, Gross National Product, Canada 1870-1926, Montreal: McGill-Queens University Press, 
1993.

Warner, Dennis and Mordechai Kreinin, "Determinants of International Trade Flows," Review of Economics and Statistics, 65, 1983, 96-104.

Wilson, John and Wendy Takacs, "Differential Responses to Price and Exchange Rate Influences in the Foreign Trade of Selected Industrial Countries," Review of Economics and Statistics, 61, 1979, 267-279.

Winters, L. Alan, "Separability and the Specification of Foreign Trade Functions," Journal of International Economics, $17,1984,239-263$.

Yadav, Gopal, "A Quarterly Model of the Canadian Demand For Imports:1956-72," Canadian Journal of Economics, 8, $1975,410-422$.

Zietz, Joachim and Donald Pemberton, "Parameter Instability in Aggregate US Import Demand Functions," Journal of International Money and Finance, 12, 1993, 654-667. 


\section{International Finance Discussion Papers}

IFDP

Number
Titles

1995

A Century of Trade Elasticities for Canada, Japan, and the United States

528

526

525

$$
\text { Modelling Inflation in Australia }
$$

Hyperinflation and Stabilisation: Cagan Revisited

On the Inverse of the Covariance Matrix in Portfolio Analysis

International Comparisons of the Levels of Unit Labor Costs in Manufacturing

Uncertainty, Instrument Choice, and the Uniqueness of Nash Equilibrium: Microeconomic and Macroeconomic Examples

Targeting Inflation in the 1990s: Recent Challenges

Economic Development and Intergenerational Economic Mobility

Human Capital Accumulation, Fertility and Growth: A Re-Analysis

Excess Returns and Risk at the Long End of the Treasury Market: An EGARCH-M Approach

The Money Transmission Mechanism in Mexico

When is Monetary Policy Effective?

Central Bank Independence, Inflation and Growth in Transition Economies
Author(s)

Jaime Marquez

Gordon de Brouwer

Neil R. Ericsson

Marcus Miller

Lei Zhang

Guy V.G. Stevens

Peter Hooper Elizabeth Vrankovich

Dale W. Henderson

Ning S. Zhu

Richard T. Freeman Jonathan L. Willis

Murat F. Iyigun

Murat F. Iyigun

Allan D. Brunner David P. Simon

Martina Copelman Alejandro M. Werner

John Ammer Allan D. Brunner

Prakash Loungani Nathan Sheets

Please adclress requests for copies to International Finance Discussion Papers, Division of International Finance, Stop 24, Board of Governors of the Federal Reserve System, Washington, D.C. 20551. 


\section{International Finance Discussion Papers}

IFDP

Number
Titles

$\underline{1995}$

518

517 from OECD countries Downturn? Superneutrality Conjecture Measurement
Alternative Approaches to Real Exchange Rates and Real Interest Rates: Three Up and Three Down

Product market competition and the impact of price uncertainty on investment: some evidence from U.S. manufacturing industries

Block Distributed Methods for Solving Multi-country Econometric Models

\section{Supply-side sources of inflation: evidence}

Capital Flight from the Countries in Transition:

Some Theory and Empirical Evidence

Bank Lending and Economic Activity in Japan: Did "Financial Factors" Contribute to the Recent

Evidence on Nominal Wage Rigidity From a Panel of U.S. Manufacturing Industries

Do Taxes Matter for Long-Run Growth?: Harberger's

Options, Sunspots, and the Creation of Uncertainty

Hysteresis in a Simple Model of Currency Substitution

Import Prices and the Competing Goods Effect

Supply-side Economics in a Global Economy

The Lucas Critique In Practice: Theory Without

Real Exchange Rate Targeting and Macroeconomic Instability
Author(s)

Hali J. Edison

William F.. Melick

Vivek Ghosal

Prakash Loungani

Jon Faust

Ralph Tryon

Prakash Loungani

Phillip Swagel

Nathan Sheets

Allan D. Brunner

Steven B. Kamin

Vivek Ghosal

Prakash Loungani

Enrique Ci. Mendoza

Gian Maria Milesi-Ferretti

Patrick Asea

David Bowman

Jon Faust

Martin Uribe

Phillip Svragel

Enrique (i. Mendoza

Linda L. 'Tesar

Neil R. Ericsson

John S. Irons

Martin Uribe 